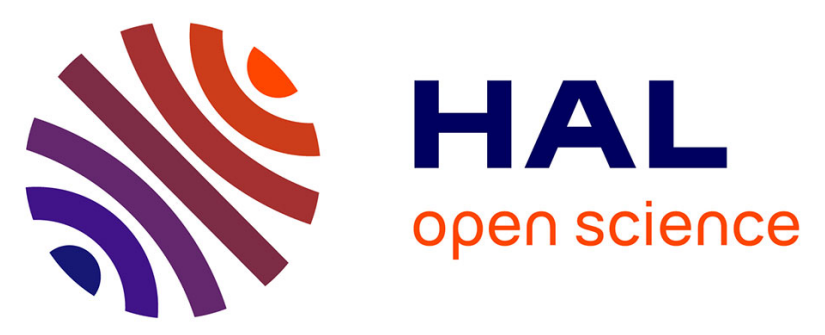

\title{
Deformation, hydration, and anisotropy of the lithospheric mantle in an active rift: Constraints from mantle xenoliths from the North Tanzanian Divergence of the East African Rift
}

Virginie Baptiste, Andrea Tommasi, Alain Vauchez, Sylvie Demouchy, Roberta L. Rudnick

\section{To cite this version:}

Virginie Baptiste, Andrea Tommasi, Alain Vauchez, Sylvie Demouchy, Roberta L. Rudnick. Deformation, hydration, and anisotropy of the lithospheric mantle in an active rift: Constraints from mantle xenoliths from the North Tanzanian Divergence of the East African Rift. Tectonophysics, 2015, 639, pp.34-55. 10.1016/j.tecto.2014.11.011 . hal-01121552

\author{
HAL Id: hal-01121552 \\ https://hal.science/hal-01121552
}

Submitted on 1 Nov 2021

HAL is a multi-disciplinary open access archive for the deposit and dissemination of scientific research documents, whether they are published or not. The documents may come from teaching and research institutions in France or abroad, or from public or private research centers.
L'archive ouverte pluridisciplinaire HAL, est destinée au dépôt et à la diffusion de documents scientifiques de niveau recherche, publiés ou non, émanant des établissements d'enseignement et de recherche français ou étrangers, des laboratoires publics ou privés.

\section{(ㄷ)(i)}

Distributed under a Creative Commons Attribution| 4.0 International License 


\title{
Deformation, hydration, and anisotropy of the lithospheric mantle in an active rift: Constraints from mantle xenoliths from the North Tanzanian Divergence of the East African Rift
}

\author{
Virginie Baptiste ${ }^{\mathrm{a}}$, AndréaTommasi ${ }^{\mathrm{a}}$, Alain Vauchez ${ }^{\mathrm{a}}$, Sylvie Demouchy ${ }^{\mathrm{a}}$, Roberta L. Rudnick ${ }^{\mathrm{b}}$ \\ a Géosciences Montpellier, Université Montpellier 2 \& CNRS, CC 60, Place E. Bataillon, 34095 Montpellier cedex 5, France \\ ${ }^{\mathrm{b}}$ Department of Geology, University of Maryland, College Park, MD 20742, USA
}

\begin{abstract}
We have analyzed the microstructures and crystal preferred orientations (CPO), and calculated the seismic properties of 53 mantle xenoliths from four localities within the North Tanzanian Divergence of the East African rift: two within the rift axis and two in the transverse volcanic belt. Olivine $\mathrm{OH}$ concentrations were measured in 15 xenoliths. Most samples have harzburgitic to dunitic compositions and high olivine Mg\#. Microstructures and olivine CPO patterns vary strongly depending on the location. In-axis peridotites display mylonitic to porphyroclastic micro-structures, which record recent deformation by dislocation creep. Highly stretched orthopyroxenes in mylonites indicate that the deformation was initiated under high stress and probably low temperature. Orthopyroxene replacement by olivine in mylonitic and porphyroclastic peridotites suggest syn-kinematic melt-rock reactions and further deformation under near-solidus conditions. Exsolutions in orthopyroxene imply significant cooling between melt-assisted deformation and xenolith extraction. Late metasomatism is evidenced by the occurrence of veins crosscutting the microstructure and interstitial clinopyroxene and phlogopite. Axial-[100] olivine CPOs predominate, suggesting activation of the high temperature, low pressure [100] $\{0 \mathrm{kl}\}$ slip systems and, probably, transtensional deformation. In the volcanic belt, Lashaine peridotites display very coarse-granular textures, indicating deformation by dislocation creep under low deviatoric stress conditions followed by annealing. Axial-[010] olivine CPOs are consistent with transpressional deformation or simultaneous activation of the $[100](010)$ and [001](010) slip systems. Intermediate microstructures and CPOs in Olmani suggests heterogeneous deformation within the volcanic belt. Olivine $\mathrm{OH}$ concentrations range between 2 and $12 \mathrm{ppm} w \mathrm{wt} . \mathrm{H}_{2} \mathrm{O}$. No systematic variations are observed between in- and off-axis samples. Maximum $P$ wave azimuthal anisotropy (AVp) ranges between 3.3 and $18.4 \%$, and the maximum $\mathrm{S}$ wave polarization anisotropy (AVs) between 2.3 and $13.2 \%$. Comparison between seismic properties of in-axis peridotites and SKS splitting data suggests transtensional deformation in the lithospheric mantle beneath the rift.
\end{abstract}

\section{Introduction}

Continental rifting is a complex process that results in localized thinning and, in some cases, in disruption of a continental plate. While the surface expression of this deformation is clear and usually well understood, little is known about how the lithospheric mantle deforms to accommodate rifting. The widely differing surface expression of continental rifting has led to contrasting lithospheric extension models. McKenzie (1978) proposed a symmetrical rift model, where the lithosphere deforms by homogeneous thinning and stretching in response to far field extensional forces. To account for the observations in the Basin and Range, Wernicke $(1981,1985)$ proposed an asymmetrical

\footnotetext{
* Corresponding author. Tel.: + 33 467144912; fax: + 33467143603

E-mail address: virginie.baptiste@gm.univ-montp2.fr (V. Baptiste).
}

extension model, in which the deformation is localized on a lithospheric-scale detachment fault. However, such models cannot account for the narrow rift valley and the strong mantle lithosphere thinning observed in East Africa (Dugda et al., 2007, 2009). The latter observations are in better agreement with the Nicolas et al. (1994) model, where rifting occurs via lithospheric rupture and rise of an asthenospheric wedge within the lithospheric mantle. The later model has been further developed by Vauchez et al. (1997) and Tommasi and Vauchez (2001), who, based on the analysis of the influence of inherited structures on the localization of continental breakup, suggested that most major rifts start forming through a transtensional deformation regime produced by the reactivation of the olivine crystallographic fabric frozen in the lithospheric mantle. Numerical models in which the upper mantle has an anisotropic viscosity controlled by the evolution of olivine crystallographic orientations corroborate this 
assumption (Tommasi et al., 2009). Rheological heterogeneities, both in the crust and in the mantle, also have a major effect on the localization of rifting (e.g., Dunbar and Sawyer, 1989; Nyblade and Brazier, 2002; Vauchez et al., 1997).

In addition to being deformed by an extensional regime, the lithosphere within an active rift is often subjected to extensive magma percolation. Dyke intrusions have been proposed to help initiate extension in a thick continental lithosphere (Buck, 2006). The major role of magmas in rifting has been corroborated by seismic anisotropy data in the Afars, which unambiguously point to aligned melt pockets throughout the crust and lithospheric mantle (Bastow et al., 2010; Kendall et al., 2005). At smaller scales, the presence of melt may result in weakening of mantle rocks (Hirth and Kohlstedt, 2003; Zimmerman and Kohlstedt, 2004). It may trigger strain localization if melt is heterogeneously distributed (e.g., Le Roux et al., 2008) or promote homogeneous deformation if it is homogeneously distributed through a large volume (Vauchez et al., 2012). Melt- or fluid-rock reaction may also result in softening through crystallization of weaker phases and/or associated grain size reduction and phase mixing (e.g., Dijkstra et al., 2002; Soustelle et al., 2010).

Mantle xenoliths provide a valuable means by which to study the deformation of mantle lithosphere during rifting. They allow for quantification of the hydration state and characterization of melt-rock reactions and of their timing relative to the deformation. Moreover, the analysis of the microstructures and crystallographic preferred orientations (CPO) bring constraints on the deformation mechanisms and conditions in the lithospheric mantle below active rifts. In the present study, we explore the relations between deformation, melt or fluids percolation, and hydration in a series of mantle xenoliths from four localities in the North Tanzanian Divergence region (East African Rift). This region, still in the early stages of rifting, offers favorable conditions to study the expression of rifting on the lithospheric mantle. In addition, we estimate the seismic anisotropy of these rocks based on their CPO and mineralogical composition and compare these results to seismic anisotropy measurements performed within and around the East African Rift.

\section{Geological setting}

The East African Rift is one of the few active continental rifts on Earth. It extends over $\sim 4000 \mathrm{~km}$, from the Afar triple junction in the Red Sea to the Gulf of Mozambique (Fig. 1), mostly following the trend of older orogenic belts (Nyblade and Brazier, 2002; Vauchez et al., 1997 and references therein). Rifting and volcanism started 35 Ma ago in Ethiopia and northern Kenya (MacDonald et al., 2001; Morley et al., 1992). It migrated southwards, reaching southern Kenya 8-5 Ma ago (Cerling and Powers, 1977; Crossley and Knight, 1981). The youngest section of the East African Rift splits into two branches around the Tanzania craton. In the Eastern branch, extension is accompanied by intense magmatic activity concentrated within the rift valley. The region experiences relatively intense present-day seismic activity, with earthquakes mainly located within the rift valley or in its immediate surroundings (e.g., Albaric et al., 2010; Nyblade et al., 1996). A major faulting episode at $1.0 \pm 0.2 \mathrm{Ma}$ (MacIntyre et al., 1974) gave rise to the present-day rift valley morphology. In addition, off-axis volcanic activity is observed in the North Tanzanian Divergence, south of which rifting occurs in a more diffuse manner, with deformation accommodated in many branches (Fig. 1). Seismic studies show that crustal and lithospheric thicknesses in this young rifting domain vary between 36-44 km and 100-150 km, respectively (Dugda et al., 2009; Julià et al., 2005).

Mantle xenoliths occur in both in- and off-axis volcanoes, providing an exceptional opportunity to study the tectono-thermal evolution of the mantle lithosphere in response to the progression of the East African Rift along the boundary between the Tanzanian craton and the Neoproterozoic Mozambique Belt. The present study focuses on 53 mantle xenoliths from four localities from the North Tanzanian Divergence (Fig. 1): two within the rift valley (Pello Hill and Eledoi) and

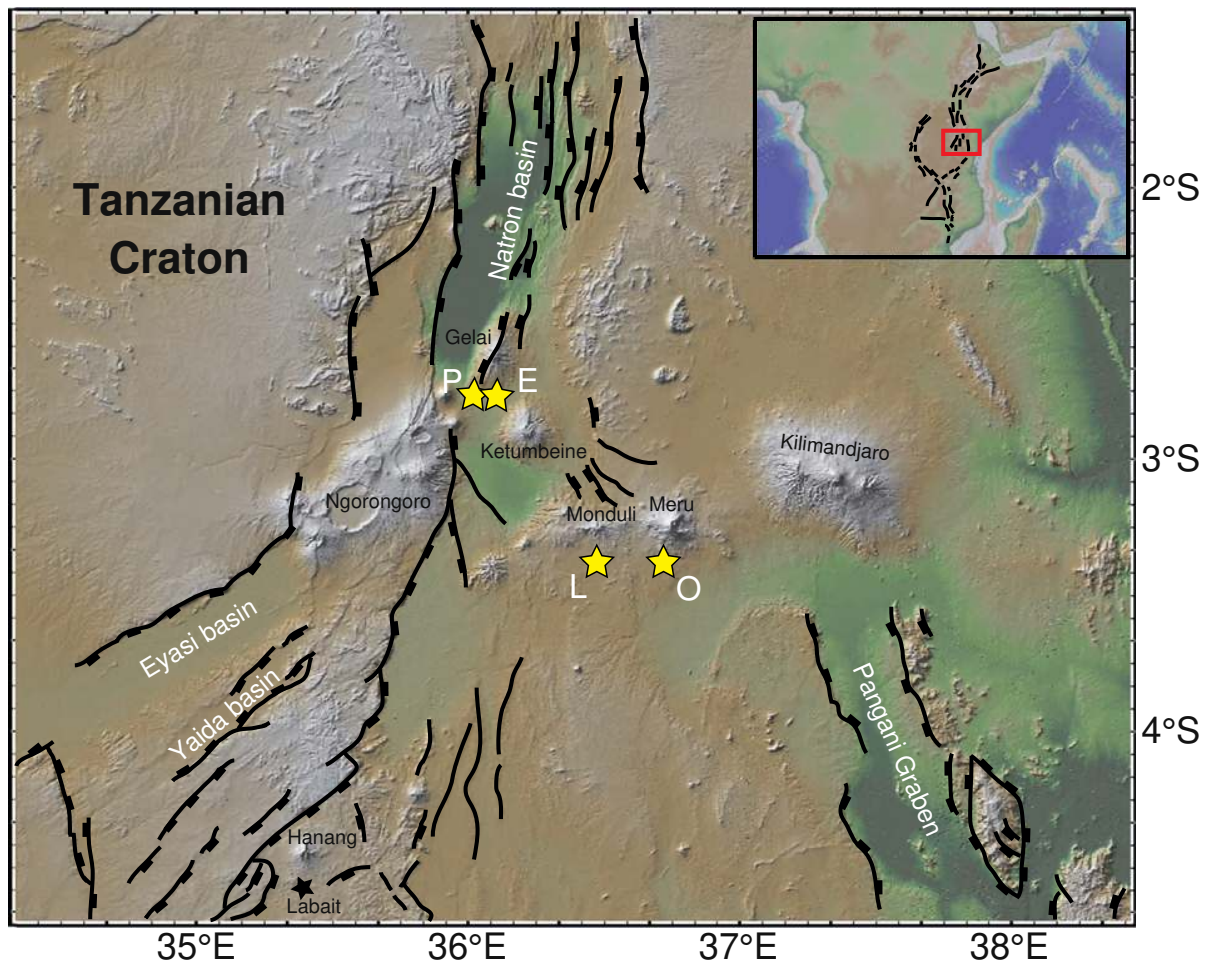

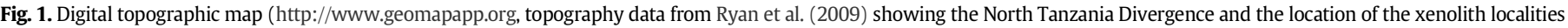

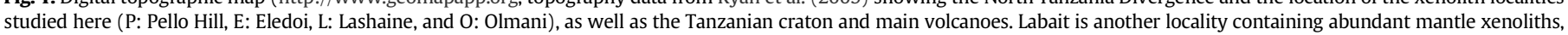
which microstructures and crystal preferred orientations were studied by Vauchez et al. (2005). 
two within the transverse volcanic belt (Lashaine and Olmani). The xenoliths from the cratered tuff cone of Pello Hill and from the Eledoi explosion crater were collected in fine-grained scoria with a bulk-rock chemistry similar to olivine-melilitites and olivine-nephelinites (Dawson and Smith, 1988). The formation of these craters postdates the major rift faulting episode at 1.2 Ma (Dawson and Smith, 1988). The Lashaine tuff cone and the Olmani cinder cone are ankaramite rift-related volcanoes erupted during the Neogene. They are located in a part of the Mozambique Belt characterized by Archean crustal material reworked in the Neoproterozoic by the Mozambique orogeny (Mansur et al., 2014 and references therein; Möller et al., 1998).

\section{Methods}

\subsection{Pressure and temperature estimates}

Major elements composition of olivine, orthopyroxene, clinopyroxene, garnet, and spinel were analyzed in 15 samples using a Cameca SX100 electron microprobe at Microsonde Sud facility, in Montpellier (France). Analytical conditions were a $20 \mathrm{kV}$ accelerating voltage and a $10 \mathrm{nA}$ probe current. Core and rim composition of 3 to 4 grains were measured for each mineral (mineral compositions of the analyzed samples presented in the online Supplementary Material Table 1).

When orthopyroxene and clinopyroxene were both present, the sample equilibrium temperature was calculated using the two pyroxenes Fe-Mg exchange geothermometer from Brey and Köhler (1990), which has an uncertainty of $\pm 50{ }^{\circ} \mathrm{C}$. However, many of the samples are clinopyroxene-free harzburgites to dunites. To verify if other thermometers (Brey and Köhler, 1990; Fabriès, 1979; Li et al., 1995; Sachtleben and Seck, 1981; Wells, 1977; Witt-Eickschen and Seck, 1991) could be used to calculate the equilibrium temperatures for the clinopyroxene-free peridotites, the consistency between the temperatures calculated with the two pyroxenes geothermometer of Brey and Köhler (1990) and these thermometers was tested for the clinopyroxene-bearing peridotites. Because the discrepancies between the equilibrium temperatures obtained using different thermometers were large, we choose not to present temperatures calculated for the clinopyroxene-free samples. The equilibrium pressure was estimated in one garnet-bearing harzburgite from Lashaine (LS11) using the orthopyroxene-garnet barometer of Nickel and Green (1985), which has uncertainties of 0.2 GPa.

\subsection{Electron-backscattered diffraction (EBSD)}

The crystallographic preferred orientation (CPO) of olivine, pyroxenes, pargasite, phlogopite, spinel, and garnet was measured by indexation of electron back-scattered diffraction (EBSD) patterns at the SEM-EBSD facility, Geosciences Montpellier. These patterns are produced by interaction of a vertical incident electron beam and a carefully polished thin section tilted at $70^{\circ}$ to the horizontal. Measurements were performed in a JEOL JSM 5600 scanning electron microscope using an acceleration voltage of $17 \mathrm{kV}$ and a working distance of $23 \mathrm{~mm}$. For each sample, maps covering nearly the entire thin section were obtained using steps between 100 and $30 \mu \mathrm{m}$, depending on grain size. Indexing rates varied between 60 to $90 \%$ depending of the mineral species and degree of fracturing present in the thin section. Phlogopite, when present, was usually poorly indexed. Orthopyroxene was sometimes misindexed as clinopyroxene. Careful post-acquisition data treatment controlled by comparison between EBSD maps and microscopic observations was performed to reduce inaccurate mineral determination as well as misindexation due to olivine pseudosymmetry. Modal composition, grain sizes, and shape-preferred orientations were also obtained from the EBSD maps.

Crystal-preferred orientation data are displayed in pole figures, presented as lower hemisphere stereographic projections. Data were plotted as one point per grain to prevent over-representation of large grains. When the foliation and lineation could be identified, the orientation of the main crystallographic directions: [100], [010] and [001] for olivine and pyroxenes, was plotted relatively to the principal axes of the deformation ellipsoids X, Y, and Z. Because the foliation and lineation could not be identified in coarse-grained samples, thin sections were cut in random orientations. To make comparison between different samples easier, we rotated the CPO of randomly oriented samples into a common orientation in which the maximum concentration of olivine [100] and [010] axes are parallel to the E-W and the N-S directions of the pole figure, respectively.

To characterize the olivine $\mathrm{CPO}$ symmetry we computed the dimensionless BA index (where B and A stand for [010] and [100] axes, respectively, Mainprice et al., 2014) defined as:

BAindex $=\frac{1}{2}\left(2-\left(\frac{P 010}{G 010+P 010}\right)-\left(\frac{G 100}{G 100+P 100}\right)\right)$

where P and G are the Point and Girdle fabric indices (Vollmer, 1990) of the olivine principal axes [100] and [010]. These indexes were calculated from the eigenvalues of the normalized orientation matrix using the MTEX texture analysis Matlab toolbox (Hielscher and Schaeben, 2008; Mainprice et al., 2011). The BA index allows a classification of the olivine CPO symmetry into 3 types: axial-[010] (BA index $<0.35)$, orthorhombic $(0.35<\mathrm{BA}$ index $<0.65)$, and axial[100] (BA index $>0.65$ ).

The strength of the fabric was quantified using the dimensionless $\mathrm{J}$-index, which is the volume-averaged integral of squared orientation densities:

$\mathrm{J}_{\mathrm{ODF}}=\int|\mathrm{f}(\mathrm{g})|^{2} \mathrm{dg}$

where $\mathrm{f}(\mathrm{g})$ is the orientation distribution function (ODF) and $\mathrm{dg}=$ $\mathrm{d} \varphi_{1} \mathrm{~d} \varphi \mathrm{d} \varphi_{2} \sin \varphi \pi^{2}$ (Bunge, 1982). $\varphi_{1}, \psi$, and $\varphi_{2}$ are the Euler angles that define the rotations allowing for coincidence between the crystallographic and external reference frames. Olivine CPO in natural peridotites is characterized by J-indexes mostly between 2 and 20, with a peak at 8-10 (Ben Ismaïl and Mainprice, 1998; Tommasi et al., 2000). The J-index for each sample was calculated based on the mean orientation of each grain using the MTEX texture analysis Matlab toolbox (Hielscher and Schaeben, 2008).

\subsection{Seismic properties}

Seismic properties of Tanzanian xenoliths were calculated using the $\mathrm{CPO}$ of all major phases and their respective modal content estimated from EBSD maps (Mainprice, 1990). For olivine, orthopyroxene, clinopyroxene, garnet, amphibole, and phlogopite single-crystal elastic constant tensors at ambient conditions were used (Abramson et al., 1997; Bezacier et al., 2010; Chai et al., 1997a, 1997b; Collins and Brown, 1998). A Voigt-Reuss-Hill averaging was applied in all calculations. The seismic anisotropy parameters and the elastic constants of all samples are presented in Table 1 and online Supplementary Material 2 , respectively.

Average seismic properties were also calculated for Lashaine, Olmani, and rift axis localities by averaging the individual samples elastic constant tensors for each locality. This calculation results in a maximum estimation of the seismic anisotropy for the locality, as it relies on the assumption of a common orientation of the foliation and lineation for all samples.

\subsection{Fourier transform infrared spectroscopy (FTIR)}

Fifteen double-polished thin sections were prepared for unpolarized FTIR analysis. Before analysis, the sections were immersed in pure acetone for at least $12 \mathrm{~h}$ to dissolve any intergranular CrystalBond glue. FTIR spectroscopy analyses were performed at the Laboratoire des Colloïdes, Verres, Nanomatériaux at Montpellier University using a Bruker IFS66v coupled with a Bruker HYPERION microscope and 
mercury-cadmium-telluride (MCT) detector cooled by liquid nitrogen. A Globar light source and a $\mathrm{Ge}-\mathrm{KBr}$ beam splitter were used to generate unpolarized mid-infrared radiation. A background measurement was performed at the beginning of the analysis of each sample and repeated when necessary. Measurements were done on olivine, orthopyroxene, and garnet crystals with beam spots of 30 to $100 \mu \mathrm{m}$. No measurement could be made on clinopyroxene crystals, which were too small and too altered. Two hundred scans were accumulated with a resolution of $4 \mathrm{~cm}^{-1}$ for each measurement. A baseline correction was applied on each spectrum using the OPUS software. Spectra were then normalized to a sample thickness of $1 \mathrm{~cm}$. The sample thickness was measured using a micrometer with a tolerance of $\pm 1 \mu \mathrm{m}$, and was always near $500 \mu \mathrm{m}$ (Table 2). Fractures and inclusions were strictly avoided.

The calibration of Paterson (1982) was used to quantify the $\mathrm{OH}$ concentration:

$C_{\mathrm{OH}}=\frac{X_{i}}{150 \zeta} \int \frac{k(\bar{v})}{(3780-\bar{v})} d \bar{v}$

where $\mathrm{C}_{\mathrm{OH}}$ is the hydroxyl concentration (in $\mathrm{mol} \mathrm{H} / \mathrm{l}$ ), $\zeta$ is an orientation factor ( $1 / 3$ for unpolarized measurements), and $k(\bar{\nu})$ is the absorption coefficient in $\mathrm{cm}^{-1}$ for a given wavenumber $\bar{v}$. $\mathrm{X}_{\mathrm{i}}$ is a density factor, which depends on the mineral phase $\left(\mathrm{X}_{\mathrm{i} \text { (ol, Fo90) }}=2695\right.$ wt. ppm $\mathrm{H}_{2} \mathrm{O}$, $\mathrm{X}_{\mathrm{i} \text { (orthopyroxene) }}=2812 \mathrm{wt}$. ppm $\mathrm{H}_{2} \mathrm{O}$ ). The uncertainty in the resulting $\mathrm{OH}$ concentrations is $\sim 30 \%$ (Kohlstedt et al., 1996).

We also converted the olivine $\mathrm{OH}$ concentrations (See Table 2) obtained using the calibration of Paterson (1982) to the new calibration of Withers et al. (2012). The conversion factor between the two calibrations is a function of the sample thickness and of the $\mathrm{OH}$ concentration obtained with the calibration of Paterson (1982). Here, the sample thickness ranges between 476 and $567 \mu \mathrm{m}$ and the olivine $\mathrm{OH}$ concentrations range between 1 and 18 wt. ppm $\mathrm{H}_{2} \mathrm{O}$. Therefore, the olivine $\mathrm{OH}$ concentrations must be multiplied by a factor of 1.8 (see Withers et al., 2012, Supplementary material Fig. 1).

\section{Results}

\subsection{Compositions and equilibrium conditions}

All samples are garnet-free peridotites, except for four Lashaine peridotites (LS11, LS4, L1, and 89-680). Most samples have harzburgitic to dunitic compositions (Fig. 2 and Table 1). Orthopyroxene contents vary mainly between 0 and $20 \%$, but several samples from Lashaine, Olmani and Pello Hill display higher modal orthopyroxene contents (22 to 32\%) and two samples from Olmani have $>50 \%$ orthopyroxene (OL3 and 03TZ14K). Secondary minerals present in diffuse veins or pockets include clinopyroxene, amphibole, phlogopite, and spinel. Veins may comprise up to $15 \%$ of the total rock (modal contents including the veins are given in parentheses in Table 1).

Mineral compositions are presented in the online Supplementary Material Table 1. In most samples, olivine has a high Mg\# (Mg\#: atomic $\mathrm{Mg} /(\mathrm{Fe}+\mathrm{Mg})$ ), which varies between 90.1 and 94.4 (Table 1 ). Seven samples (out of the forty-one for which the olivine Mg\# has been measured) have more Fe-rich olivines (Fo $\leq 89$ ). Among these samples, 4 are very-coarse granular dunites from Olmani or from the rift axis localities (EL14, PEL11, PEL41, 89-772). The 3 other Fe-rich samples are: a harzburgite from Olmani with high orthopyroxene contents (>50\%; 03TZ14K), a granular dunite from Lashaine (LS15), and a porphyroclastic harzburgite from Pello Hill (PEL1). There is no significant difference between olivine $\mathrm{Mg} \#$ for samples from the in-axis and off-axis localities. Olivine always has $\mathrm{NiO}>0.25 \mathrm{wt} . \%$ and low $\mathrm{CaO}$ ( $\leq 0.11$ wt.\%). Orthopyroxenes are enstatite, with $\mathrm{Mg \#}>90$. Clinopyroxenes are $\mathrm{Cr}$-bearing diopside $\left(\mathrm{Cr}_{2} \mathrm{O}_{3}\right.$ comprised between 1.0 and 3.7 wt.\%) with Mg\# $>90$, except for sample EL15 where $\mathrm{Cr}_{2} \mathrm{O}_{3}<0.1$ wt.\% and lower Mg\# are measured. Spinels have high $\mathrm{MgO}$
(10-17 wt.\%) and variable $\mathrm{Cr} \#$ (atomic $\mathrm{Cr} /(\mathrm{Cr}+\mathrm{Al})$ ), ranging between 36 and 89.

We have been able to estimate equilibrium temperatures for only 9 of the 15 samples analyzed, because the others lacked clinopyroxene. Independently of their provenance or microstructure, all these samples have core equilibrium temperatures (calculated from core compositions in orthopyroxene and clinopyroxene) between 1000 and $1100{ }^{\circ} \mathrm{C} \pm 50^{\circ} \mathrm{C}$ (Table 1). Rim equilibrium temperatures (calculated from rim compositions in orthopyroxene and clinopyroxene) tend to be slightly, but systematically lower (by $5-21{ }^{\circ} \mathrm{C}$ ), except for sample PEL22 from Pello Hill, where rim equilibrium temperature is lower than core equilibrium temperature by $>100{ }^{\circ} \mathrm{C}\left(960{ }^{\circ} \mathrm{C}\right.$ versus $\left.1090{ }^{\circ} \mathrm{C}\right)$. In a garnet harzburgite from Lashaine (LS11), core and rim equilibrium pressures of $3.3 \mathrm{GPa}$ and 3.1 GPa were obtained, respectively.

\subsection{Microstructures}

Because of their very different characteristics, the xenoliths microstructures will be described as a function of their provenance: the rift axis (Pello Hill and Eledoi) or the transverse volcanic belt (Lashaine and Olmani).

\subsubsection{Rift axis samples}

The xenoliths from volcanic localities within the rift axis display variable microstructures. Among the 27 studied xenoliths, 2 are mylonitic, 22 are porphyroclastic, and 3 are coarse-granular to tabular.

Mylonitic microstructures are only observed in 2 samples from Pello Hill (PEL15 and PEL17; Fig. 3a). These rocks are characterized by centimeter-sized orthopyroxenes, which are highly elongated (aspect ratios of up to 15:1), defining the lineation. These orthopyroxenes always display well-defined kink bands and undulose extinctions. They have indented grain boundaries, with olivine grains filling the embayments or even forming vein-like inclusions parallel to the orthopyroxene elongation (Fig. 4a). Exsolution in orthopyroxene is ubiquitous. Olivine is present as plurimillimetric porphyroclasts and as recrystallized grains with sizes ranging from 0.4 to $2 \mathrm{~mm}$. It displays curvilinear boundaries, evolving sometimes to polygonal shapes. Subgrain boundaries in olivine are highly oblique to perpendicular to the grains elongation. The frequency and extent of deformation features in the porphyroclasts vary, however, between the 2 samples. In mylonite PEL17, subgrain boundaries are well developed and closely spaced. In mylonite PEL15, there are fewer subgrain boundaries. In both mylonites, the olivine neoblasts exhibit few subgrain boundaries and sometimes form $120^{\circ}$ triple junctions.

The porphyroclastic peridotites (Fig. 3b, c) are the most common textural type at Pello Hill and Eledoi. They display plurimillimetric elongated olivine porphyroclasts (Fig. 3b), with common subgrain boundaries, undulose extinction, and sutured grain boundaries. Subgrain boundaries in olivine are dominantly at high angle to the foliation, but in many grains 2 orthogonal subgrain boundary families are observed (Fig. 4b). Small olivine neoblasts have fewer intracrystalline deformation features and tend to have more polygonal shapes, sometimes forming triple junctions. The frequency of the triple junctions in the recrystallized matrix and the subgrain boundaries spacing in porphyroclasts vary from sample to sample. For example, in sample PEL7, olivine porphyroclasts exhibit closely spaced subgrain boundaries and serrated grain boundaries (Fig. 4b), whereas olivine porphyroclasts in sample PEL1 display fewer subgrain boundaries and have polygonal grain boundaries (Fig. 3c). In the porphyroclastic peridotites from Eledoi, olivine porphyroclasts are rare, giving to the rock a more homogeneous microstructure. Interpenetrating olivine-olivine grain boundaries are common (Fig. 3b, c), suggesting grain boundary migration. In both sites, when present, orthopyroxene is anhedral, with intracrystalline deformation features, such as kink bands and undulose extinction. Exsolutions and corrosion embayments filled with olivine are common (Figs. 3b and 4c). 


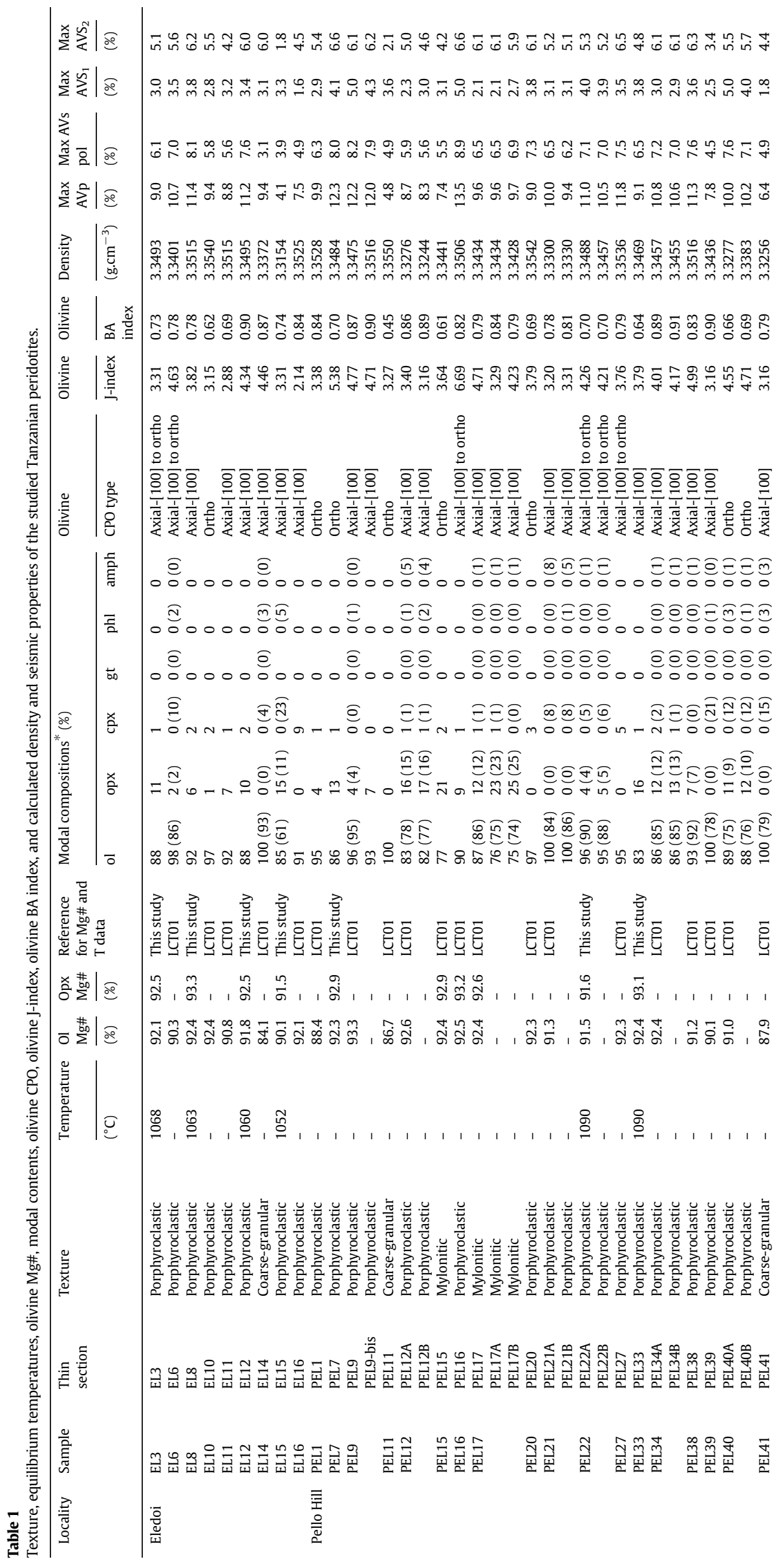




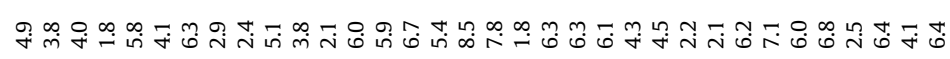

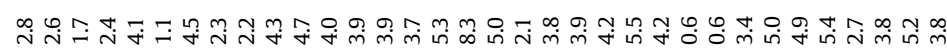

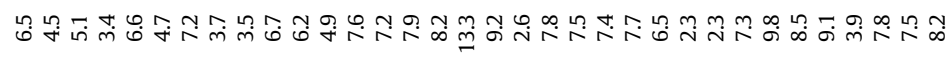

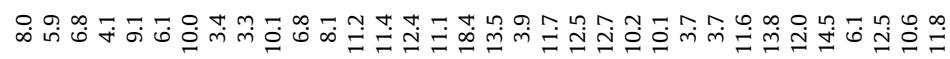

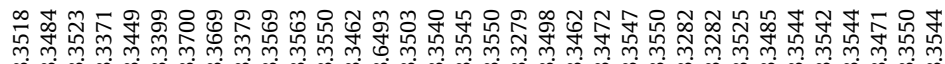

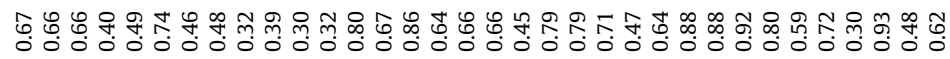

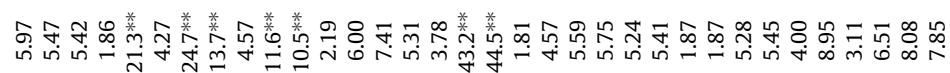

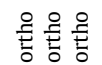

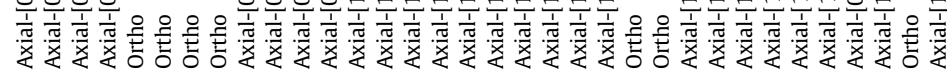

0000000000000000000000000000000000 $000-000000000000000000000000000000$

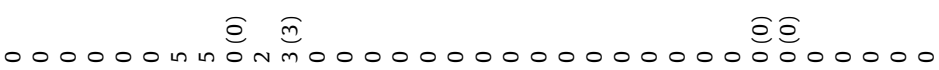

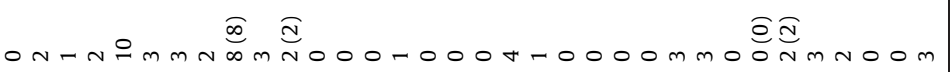

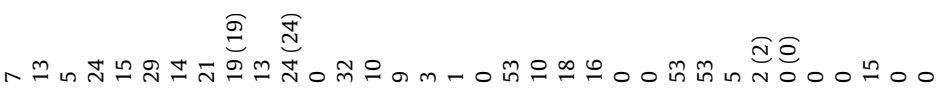

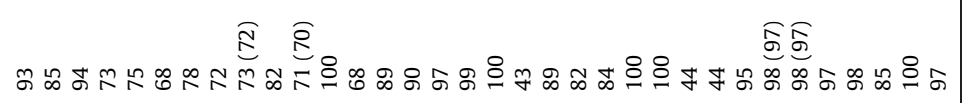
, 䒴

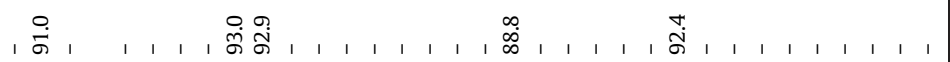

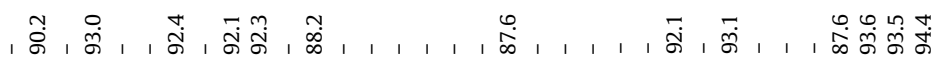

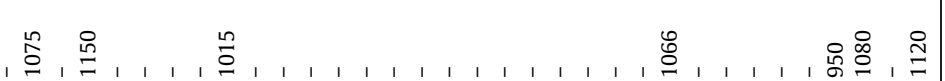

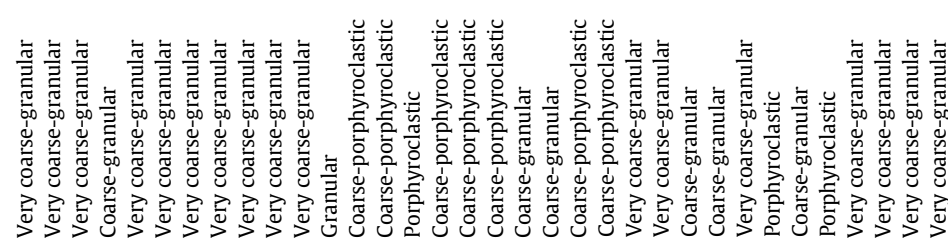

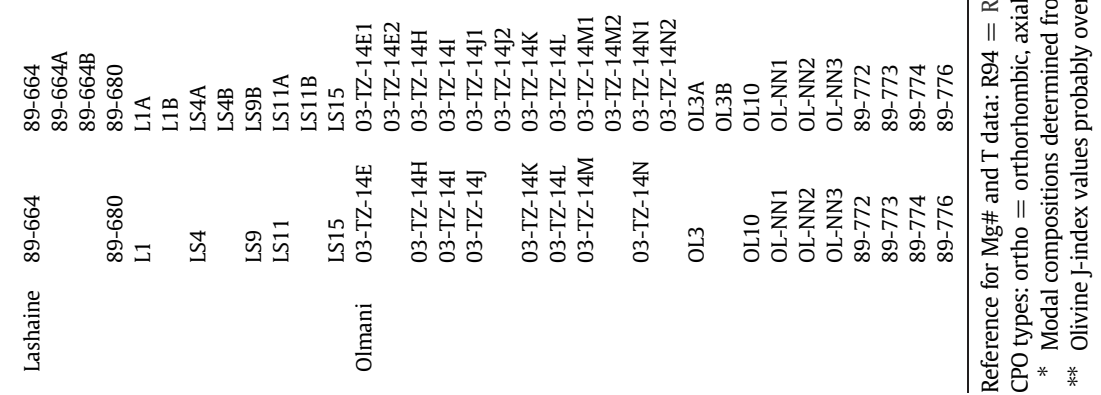




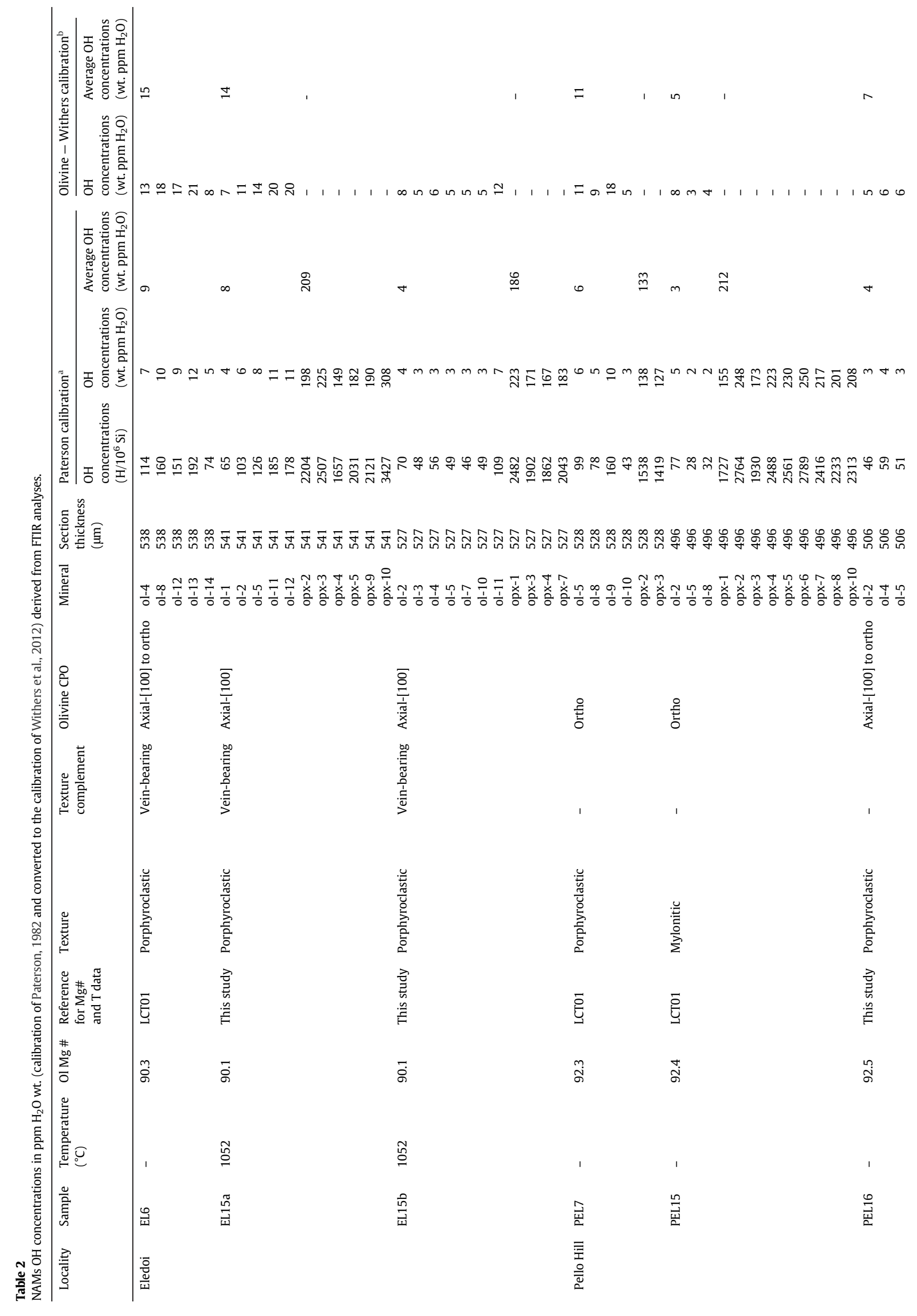




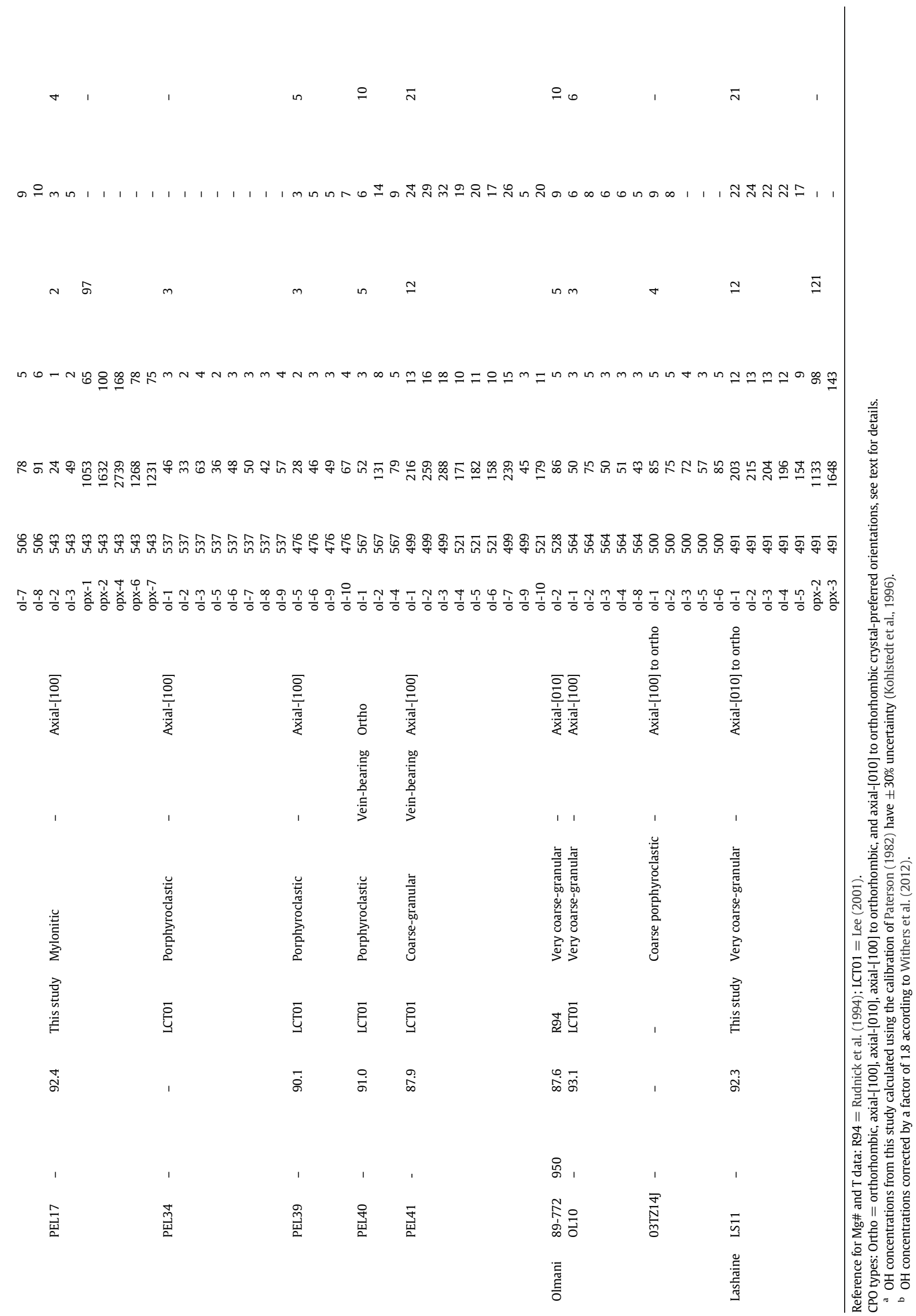


All coarse-granular to tabular peridotites are dunites (Fig. 3d, e). They exhibit coarse olivine grains $(1-8 \mathrm{~mm})$ with equant to tabular shapes. Olivine has curvilinear to polygonal boundaries and is often devoid of any substructure. $120^{\circ}$ triple junctions are common. Three coarsegranular to tabular dunites (EL14, PEL11 and PEL41) are crosscut by diffuse veins composed of millimeter-sized clinopyroxene, phlogopite, amphibole and spinel (Figs. 3d and 4d). Intracrystalline deformation features are very rarely observed in phlogopite and amphibole grains. The orthopyroxene crystals in contact with the vein are partially replaced by diopside.

In the porphyroclastic and mylonitic samples, the distribution of metasomatic minerals (phlogopite, amphibole, clinopyroxene, and spinel) is usually more diffuse. They form irregular pockets (Fig. 4e) or occur as small interstitial grains dispersed in the rock. When these minerals are dispersed in the rock, they may display subgrain boundaries. They are usually associated with fine-grained olivines, forming "bands" with smaller grain sizes. In the pockets, spinel is associated with clinopyroxene, pargasite or phlogopite (Fig. 4e).

\subsubsection{Xenoliths from the transverse volcanic belt}

The xenoliths from the two localities (Olmani and Lashaine) within the divergence exhibit different microstructures. We will thus describe them separately.

4.2.2.1. Lashaine. The xenoliths from Lashaine show mainly very coarse granular microstructures (Fig. 3f). Olivine grain size ranges from few millimeters to more than a centimeter. They have curvilinear boundaries and widely spaced subgrain boundaries. Interpenetrating grain boundaries are common. Orthopyroxene is usually smaller (1-8 mm) than olivine, with rare kink bands or undulose extinction. Exsolution in orthopyroxene is only observed in sample LS4. Lashaine is the only location where garnet peridotites (samples LS4, LS11, 89-680, and L1) were sampled. Garnet is present as irregularly-shaped crystals, several $\mathrm{mm}$ long, most often rimming orthopyroxene (marked by arrows in Fig. 3f). Kelyphitic rims are always present. In sample L1, garnet has been entirely replaced by kelyphite. Clinopyroxene is present as exsolutions in orthopyroxene or as very small interstitial crystals associated with pargasite and spinel. Olivine with interpenetrating boundaries is commonly observed (Figs. $3 \mathrm{f}$ and $4 \mathrm{~g}$ ), as well as orthopyroxene embayments filled with olivine. Peridotite LS9 displays slightly different characteristics: it contains recrystallized zones with finer-grained olivine showing curvilinear to polygonal boundaries (Fig. 4f). Olivine tablets free of any substructure are present on other olivine crystals (Fig. 4f). Orthopyroxene often contains olivine inclusions.

Two samples have granular microstructures but smaller grain sizes: the coarse-granular harzburgite 89-680 and the granular dunite LS15. In harzburgite 89-680, olivine grain size ranges mainly between 1 and $4 \mathrm{~mm}$. Olivine displays curvilinear to polygonal boundaries, and few subgrain boundaries. Orthopyroxene grain size varies between 0.5 and $2 \mathrm{~mm}$. It has irregular shapes with curvilinear boundaries and may contain kink bands. Small interstitial clinopyroxene, phlogopite and amphibole grains are present. Dunite LS15 displays even smaller olivine grain sizes, ranging between 0.5 and $2 \mathrm{~mm}$. Olivine has curvilinear, sometimes interpenetrating grain boundaries and a higher proportion of subgrain boundaries than the other samples from Lashaine.

4.2.2.2. Olmani. The peridotites from Olmani display microstructures intermediate between those described for peridotites from the rift-axis localities and from Lashaine. Among the 17 studied xenoliths, 3 are porphyroclastic, 4 are coarse-porphyroclastic, 4 are coarse-granular, and 6 are very coarse -granular.

The porphyroclastic harzburgites display elongated olivine porphyroclasts with millimetric grain sizes (Fig. 3g), which mark the foliation, and small olivine neoblasts $(0.2-1 \mathrm{~mm})$ with curvilinear to polygonal boundaries. The frequency of subgrain boundaries and the degree of polygonization of the grain boundaries vary from sample to sample. For instance, sample 03TZ14H shows interpenetrating olivineolivine grain boundaries, whereas polygonal olivine grains characterize sample OL-NN4. Orthopyroxene occurs as small ( $<1 \mathrm{~mm})$, interstitial crystals displaying rare kink bands.

In coarse-porphyroclastic harzburgites, olivine grains are millimetric to centimetric and elongated. They commonly display closely spaced subgrain boundaries and interpenetrating grain boundaries. Small olivine grains rim the porphyroclasts. These neoblasts display curvilinear to polygonal grain boundaries. Orthopyroxene usually displays irregular shapes, rare kink bands and undulose extinction, as well as common exsolutions and corrosion embayments filled with olivine. Olivine crystals included in orthopyroxene grains are sometimes observed. In sample 03TZ14M, spinel-pyroxene symplectites are observed.

In coarse-granular harzburgites, olivine and orthopyroxene grain sizes vary between 0.5 and $3 \mathrm{~mm}$. Two of these samples (OL3 and $03 \mathrm{TZ14K}$ ) display very high orthopyroxene content (>50\%). Olivine is characterized by curvilinear to polygonal boundaries and common subgrain boundaries. In 2 samples (03TZ14K and 03TZ14L), olivine is occasionally included in orthopyroxene. Orthopyroxene grains are anhedral. They display well-defined kink bands and undulose extinction, as well as exsolutions. In several orthopyroxene grains, corrosion embayments filled with olivine are present.

The very coarse-granular peridotites from Olmani are similar to the samples from Lashaine (Fig. 3h). They display millimetric to centimetric olivine grains. The density of subgrain boundaries and their spacing vary considerably from one sample to another. Interpenetrating olivine grain boundaries are always observed. Orthopyroxene is present in only 1 of these samples (89-773). In this sample, orthopyroxene has millimeter grain sizes, curvilinear boundaries, and displays well-defined kink bands.

\subsection{Crystallographic preferred orientations (CPO)}

As for the microstructures, we describe separately the CPOs of peridotites from the rift axis, Lashaine, and Olmani.

\subsubsection{Rift axis}

Most rift-axis samples have low to moderate olivine CPO strength, with J-indexes varying mainly between 2-6 (Fig. 5). There is no correlation between the olivine CPO symmetry, its strength, and the microstructure. Peridotites from Pello Hill and Eledoi exhibit olivine CPO symmetries ranging from axial-[100] to orthorhombic (Fig. 5). Axial-[100] symmetry predominates. These patterns are characterized by a point concentration of [100], which in the mylonites and porphyroclastic peridotites is close to the lineation, and a girdle distribution of [010] and [001] normal to it. One sample has a clear orthorhombic olivine $\mathrm{CPO}$, exhibiting a point concentration of the 3 crystallographic axes, with [100] showing the strongest concentration subparallel to the lineation. [010] is usually more concentrated than [001] and tends to align normal to the foliation. Many samples, like PEL27, display an intermediate pattern characterized by weak girdles of [010] and [001] normal to the maximum concentration of [100], with a concentration of [010] normal to the foliation plane and a concentration of [001] in the foliation plane parallel to the Y structural axis.

When present, orthopyroxene has more dispersed CPO, but correlated to the olivine CPO: the maximum concentration of [001] of orthopyroxene is parallel or slightly oblique to the olivine [100] maximum, except for one sample (PEL22). Orthorhombic CPO predominates, with [001] showing the strongest point concentration, which, in the mylonites and porphyroclastic peridotites, is subparallel to the lineation. In most samples, [100] axes are aligned normal to the foliation, but in some samples [010] is preferentially oriented perpendicular to the foliation.

Clinopyroxene crystals in the veins or as interstitial grains display a weak orthorhombic CPO pattern, with [001] axes showing the strongest 


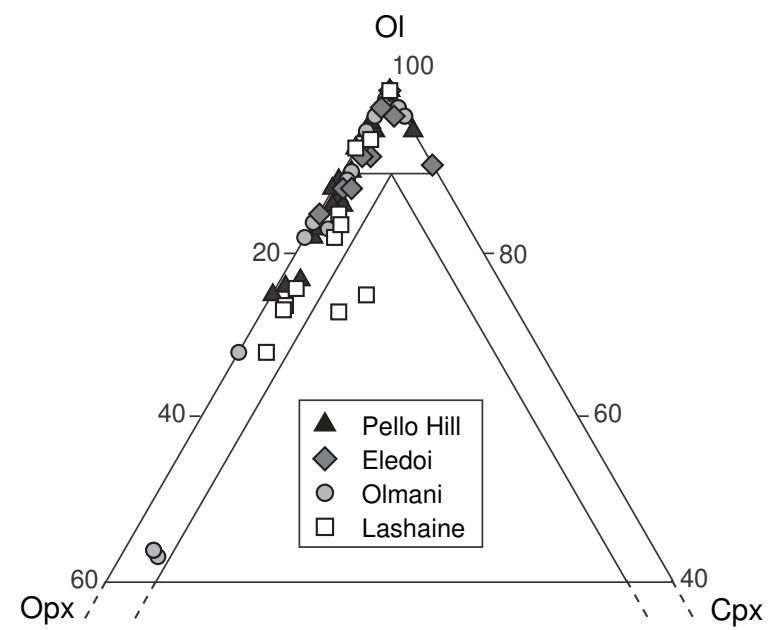

Fig. 2. Olivine-orthopyroxene-clinopyroxene modal ratios in the studied peridotites studied here. Modal compositions are derived from EBSD maps, not considering metasomatic veins and pockets, and recalculated for a total of $100 \%$ of olivine + orthopyroxene + clinopyroxene.

point concentration, which is usually subparallel to the orthopyroxene [001] maximum and to the olivine [100] maximum. The clinopyroxene $\mathrm{CPO}$ is thus coherent with those of olivine and orthopyroxene. In 12 samples, [100] axes are perpendicular to the foliation plane. In the other samples, [010] tends to be preferentially oriented normal to the foliation.

\subsubsection{Transverse volcanic belt}

4.3.2.1. Lashaine. Olivine CPO strength of Lashaine samples is more variable than for the rift axis peridotites. J-index ranges between 2 and 8 for those samples where more than 100 grains could be measured (Fig. 5). In some very-coarse grained peridotites, the number of measured grains was $<100$, leading to a possible overestimation of the Jindex (Ben Ismail and Mainprice, 1998). These values are marked by dashed arrows in Fig. 5. Olivine CPO in Lashaine peridotites varies from axial-[100] to axial-[010] patterns, with a predominance of orthorhombic patterns (BA indexes vary between 0.3 and 0.74 , Fig. 5). Three samples (LS9, LS15, and 89-680) display axial-[010] CPO, characterized by a point concentration of [010] and a girdle distribution of [100] and [001] normal to it. Two samples (L1 and LS4) display orthorhombic CPO. In 2 other samples (89-664 and LS11), CPOs with a pattern intermediate between orthorhombic and axial-[100] are observed. In these rocks, the CPO is generally weak, but a point concentration of [100] and incomplete girdles of [010] axes are observed.

Orthopyroxene CPOs are more dispersed than olivine CPOs. They are characterized by a weak point concentration of [001] axes parallel to [100] of olivine. In most samples, the maximum concentration of [100] is parallel to [010] maximum of olivine.

4.3.2.2. Olmani. The peridotites from Olmani display olivine CPO with variable strength (J-indexes vary between 2 and 9; Fig. 5). They show mainly axial-[100] to orthorhombic olivine CPO patterns (Fig. 5). Porphyroclastic samples tend to exhibit axial-[100] patterns, that is, higher olivine BA indexes, as well as higher J-indexes than granular samples. A single coarse-granular sample (89-772) is characterized by axial-[010] pattern.

When present, orthopyroxene has a CPO correlated to the olivine one. In three samples, weak axial-[010] patterns can be observed (see Fig. 5, sample OL3). They are characterized by a girdle distribution of [100] and [001] in the foliation plane and point concentration of
[010] normal to it. The other samples display weak orthorhombic CPO symmetry (Fig. 5, sample 03TZ14E1).

\subsection{Seismic properties}

Average anisotropic seismic properties for rift-axis and off-axis samples are illustrated in Fig. 6. To a first order, all localities share common seismological characteristics. The P-wave propagation is fastest close to the olivine [100] maximum, which corresponds to the lineation in the samples where it has been identified, and slowest close to [010] maxima, then normal to the foliation. The slowest propagation directions of the slow S-wave $\left(\mathrm{S}_{2}\right)$ are in the YZ structural plane. The fast split shear wave $\left(S_{1}\right)$ is polarized in a plane containing the main concentration of olivine [100] and the propagation direction. The highest $\mathrm{Vp} / \mathrm{Vs}_{1}$ ratio is also parallel to the preferred orientation of olivine [100] and the lowest $\mathrm{Vp} / \mathrm{Vs}_{1}$ is observed for waves propagating normal to this direction.

Changes in olivine CPO symmetry result in second order variations of the seismic anisotropy pattern. Within the rift axis and at Olmani, where axial-[100] and orthorhombic olivine CPOs predominate, P-wave velocities are slow and S-wave azimuthal anisotropy is high within the $\mathrm{YZ}$ plane. The fastest velocities of $\mathrm{S}_{2}$-waves are observed for directions close to the lineation. The slowest propagation of the $S_{1}$-wave occurs for directions either close or normal to the lineation, while the fastest $S_{1}$ propagation are expected for directions at $45^{\circ}$ to the lineation.

At Lashaine, where axial-[010] to orthorhombic olivine CPOs dominate, slow P-wave velocities are found for propagation directions normal to the foliation plane. In contrast to the average properties computed for the rift axis, the S-wave polarization anisotropy is very low for propagation directions at high angle to the plane containing the concentrations of [100] and [001] (corresponding to the foliation when observed), with a minimum within the $\mathrm{XZ}$ plane at $\sim 45^{\circ}$ to the lineation. The maximum $S$-wave polarization anisotropy lies within the foliation at $90^{\circ}$ to the lineation. The fastest propagation directions of $S_{1}$-wave are contained in the foliation plane, while the slowest directions are parallel to the $Z$ structural direction. Slow and fast $S_{2}$-wave propagation directions are observed in a plane normal to the lineation and in the $\mathrm{XZ}$ plane, at $45^{\circ}$ to the lineation, respectively.

Seismic anisotropy intensities for individual samples are highly variable (Fig. 7, Table 1). Maximum P-wave anisotropies are comprised between 3.3 and $18.4 \%$, while maximum S-wave polarization anisotropies range between 2.3 and $13.3 \%$. Porphyroclastic peridotites, which have the strongest olivine $\mathrm{CPO}$, tend to have the highest anisotropies, whereas granular peridotites yield the lowest anisotropies (Fig. 7). Within a microstructural group, however, there is no systematic variation in anisotropy as a function of the provenance.

We observe no simple relationship between $\mathrm{P}$ - and S-wave anisotropy intensities and the olivine CPO symmetry (characterized by the BA index; Fig. 7c, d). Most porphyroclastic peridotites, which have axial-[100] olivine CPO, are strongly anisotropic (Fig. 5).

Crystallization of large volumes of metasomatic phases (>25\% vol.) may considerably reduce $\mathrm{P}_{-}, \mathrm{S}_{1}$ - and $\mathrm{S}_{2}$-wave velocities, and the maximum $\mathrm{P}$ - and S-wave anisotropy, as illustrated by Fig. 8 , in which we compare the seismic properties of sample EL15 calculated by taking into account or not a phlogopite-bearing clinopyroxenite vein that crosscuts this sample. It reduces the $\mathrm{Vp} /$ $\mathrm{VS}_{1}$ range, by increasing the minimum values, but it has no effect on $\mathrm{Vp} / \mathrm{VS}_{2}$ ratios.

\section{5. $\mathrm{OH}$ concentrations}

\subsubsection{Olivine}

The olivine spectra of xenoliths from Pello Hill, Eledoi, Olmani, and Lashaine exhibit many absorption bands with highly variable intensities (Fig. 9a), suggesting $\mathrm{H}$ incorporation in a variety of point defects (Berry 
et al., 2005, 2007; Kovacs et al., 2010; Miller et al., 1987; Padrón-Navarta et al., 2014). In a first group of samples (LS11, PEL41, 03TZ14J, EL6, PEL39), the absorption band at $3571 \mathrm{~cm}^{-1}$ displays the maximum O-H absorbance, while the intensity of the absorption bands at 3596 and $3525 \mathrm{~cm}^{-1}$ varies. Absorption bands between 3450 and $3200 \mathrm{~cm}^{-1}$ have minor peaks, except for the band at $3226 \mathrm{~cm}^{-1}$, which can be
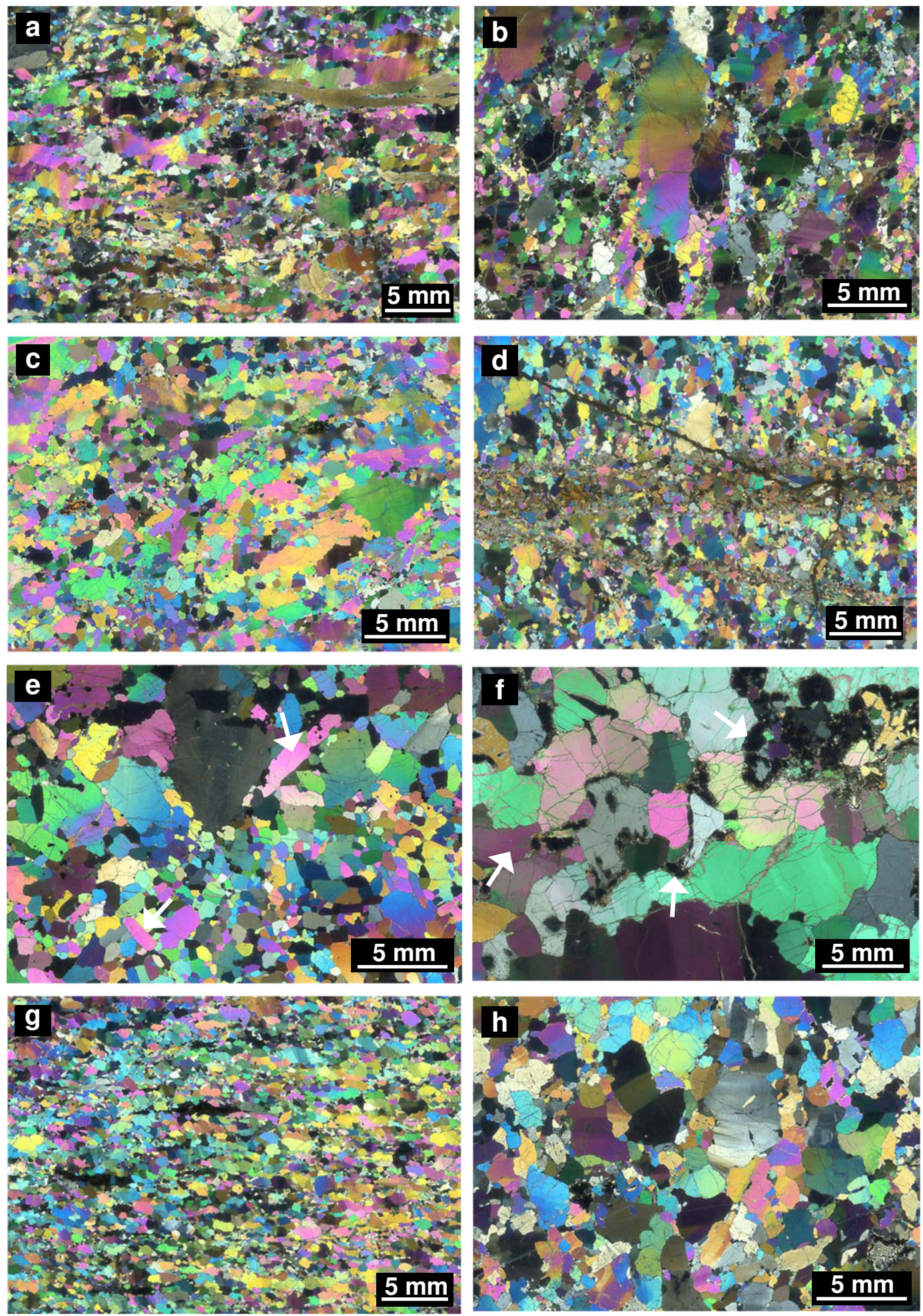

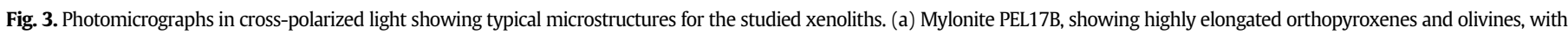

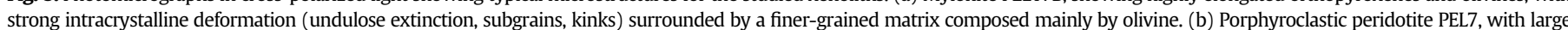

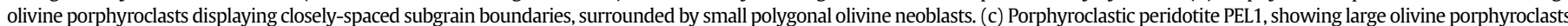

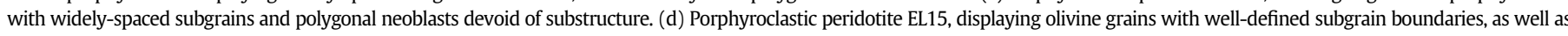

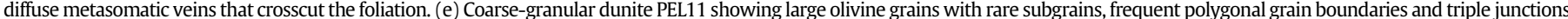

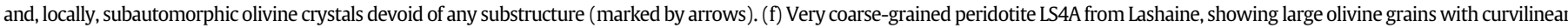

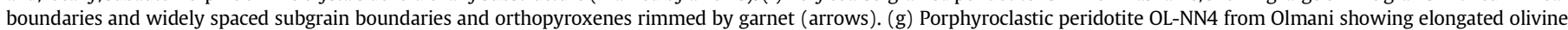
porphyroclasts with well-defined subgrain boundaries. (h) Very coarse-grained harzburgite 89-773 from Olmani, showing large olivines with curvilinear boundaries. 

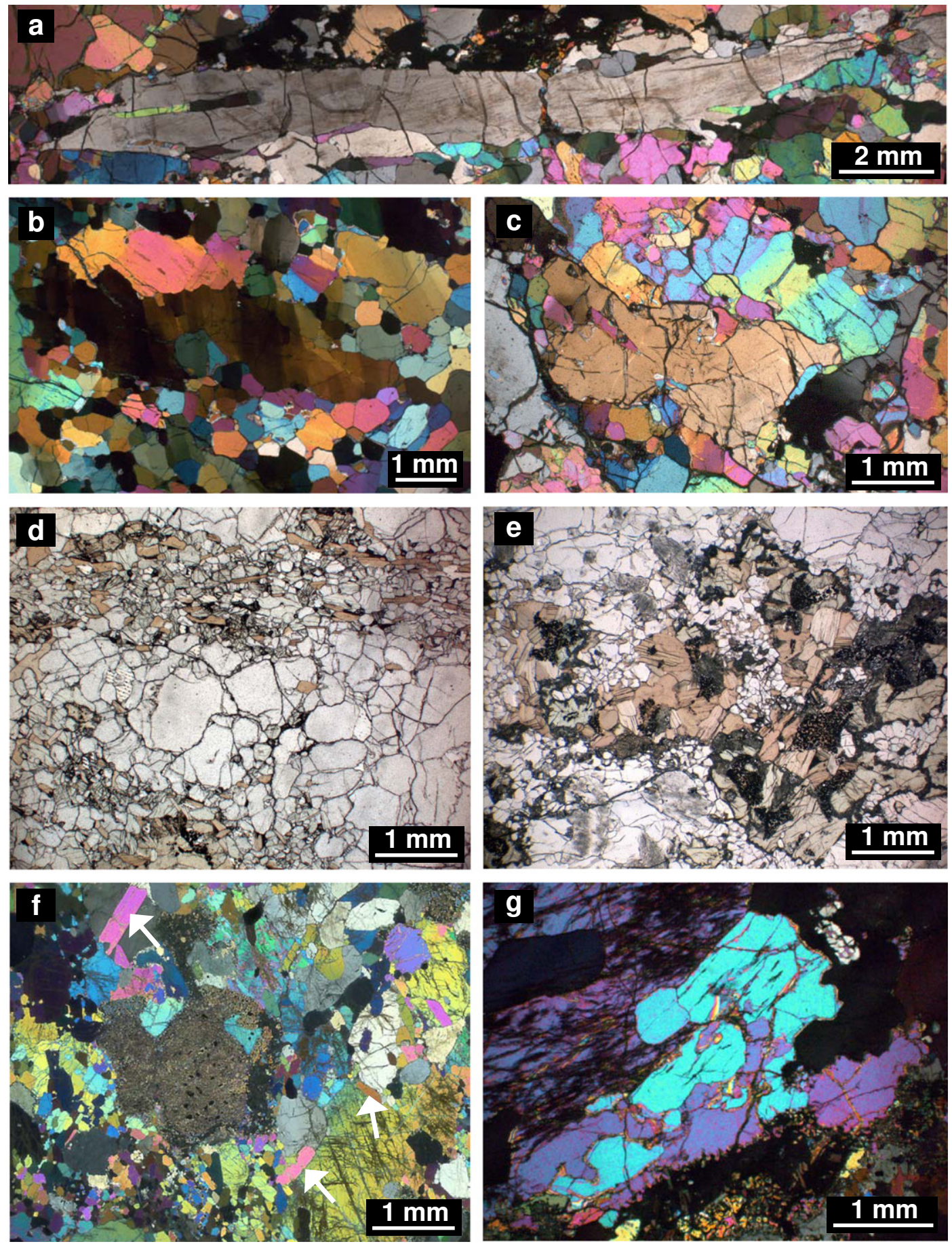

Fig. 4. Photomicrographs in cross-polarized (a, b, c, f, and g) and plane-polarized light ( $d$ and e) of: (a) Highly elongated orthopyroxene in mylonite PEL15 from Pello Hill displaying embayments filled with olivine in crystalline continuity with the surrounding grains, as well as olivine inclusions elongated parallel to the orthopyroxene elongation and displaying subgrains. (b) Elongated olivine porphyroclasts with closely-spaced subgrain boundaries in peridotite PEL1 from Pello Hill. Small neoblasts forming triple junctions are also visible. (c) Orthopyroxene displaying inclusions and embayments filled with olivine in peridotite PEL7 from Pello Hill. (d) Diffuse veins composed of clinopyroxene, phlogopite, amphibole, spinel, and olivine in peridotite PEL39 from Pello Hill. The same phases are also present as interstitial grains between the veins. (e) Phlogopite, amphibole, clinopyroxene, and spinel "pockets" in peridotite PEL12 from Pello Hill. Note the smaller grain size and more polygonal shapes of olivine within these metasomatic pockets and veins. (f) Peridotite LS9 from Lashaine, characterized by coexistence of large olivine grains and of "recrystallized" zones composed of small olivine neoblasts with polygonal shapes. Olivine tablets (arrows) growing on other grains are also visible. (g) Interpenetrating olivine-olivine grain boundaries, indicating active grain boundary migration in peridotite LS9 from Lashaine.

more developed. In a second group of samples (EL15a, PEL17, PEL7, PEL15), absorption bands between 3450 and $3200 \mathrm{~cm}^{-1}$ present major peaks, with variable intensities. Finally, in a third group of samples (PEL16, EL15b, 89-772, OL10, PEL40, PEL34), both absorption bands groups are observed.

\subsubsection{Orthopyroxene and garnet}

Orthopyroxene spectra are more homogeneous (Fig. 9b) than those of olivine. They display up to seven absorption bands. The four major bands are found at 3600, 3544, 3517 and $3410 \mathrm{~cm}^{-1}$. Their intensities are variable. Minor peaks are also present around 3473, 3324 and $3060 \mathrm{~cm}^{-1}$. 


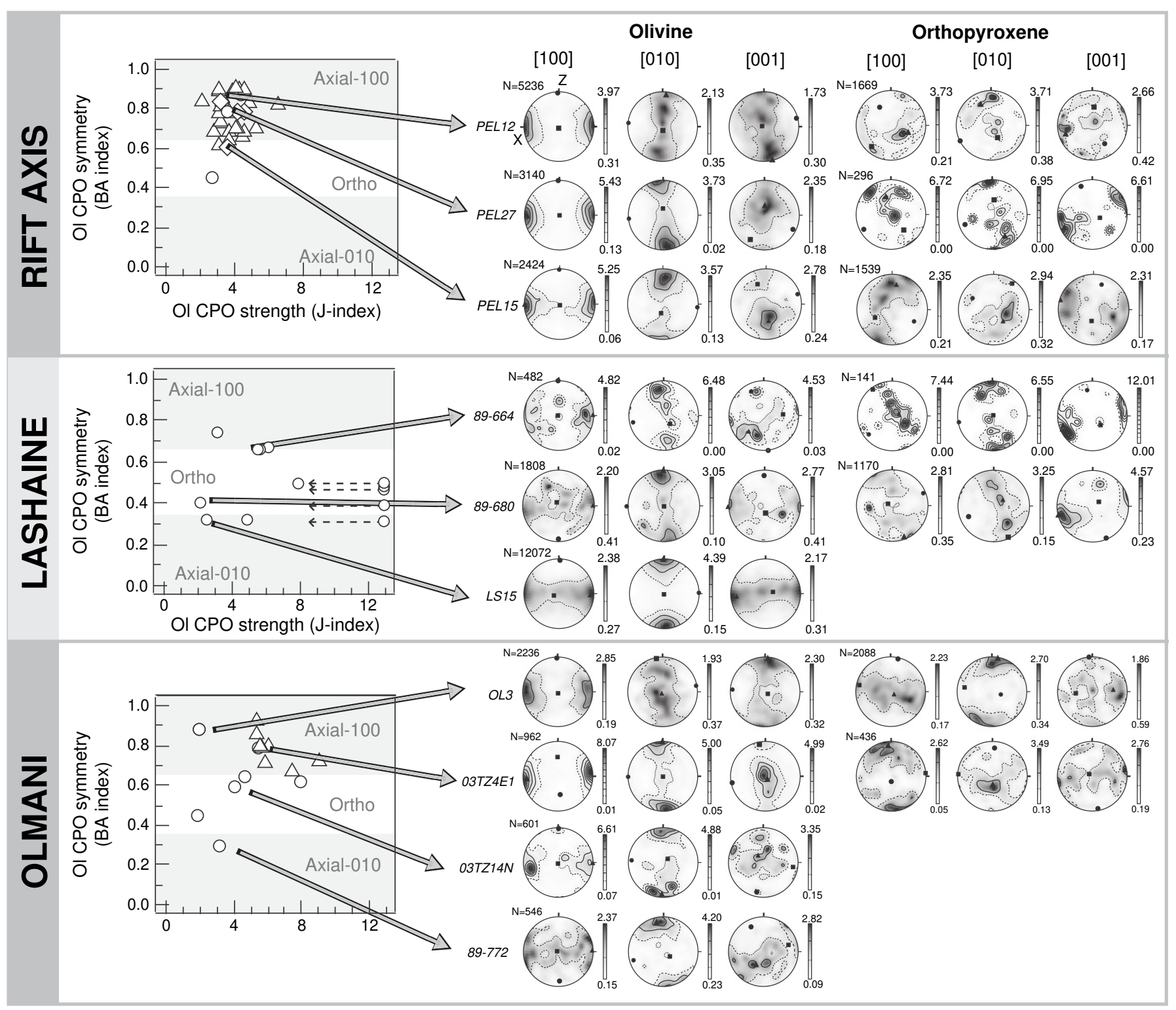

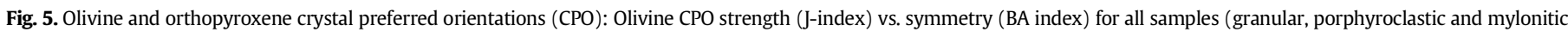

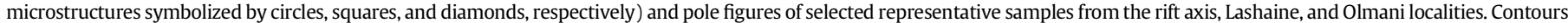

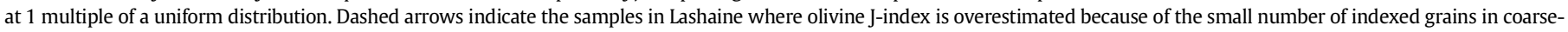
grained peridotites.

Several millimeters long clear garnet grains were present in only one of the analyzed samples (harzburgite xenolith from Lashaine LS11). Their spectra are flat, indicating anhydrous garnet.

\subsection{3. $\mathrm{OH}$ concentrations}

Olivine $\mathrm{OH}$ concentrations are heterogeneous both between and within samples. They range between 2 and 12 wt. ppm $\mathrm{H}_{2} \mathrm{O}$ (Table 2 , Figs. 10 and 11) and are in the range of concentrations previously measured for spinel peridotites (Denis et al., 2013; Falus et al., 2008; Grant et al., 2007; Kurosawa et al., 1997; Li et al., 2008; Peslier, 2010; Peslier and Luhr, 2006; Soustelle et al., 2010, 2013; Yang et al., 2008). Olivines from Pello Hill xenoliths are more heterogeneous than those from Olmani and Eledoi. However, there is no systematic correlation between olivine $\mathrm{OH}$ concentrations and provenance (Fig. 10). The lowest olivine $\mathrm{OH}$ concentrations are found in mylonites, in agreement with data from previous studies (Baptiste et al., 2012; Falus et al., 2008). The highest average olivine $\mathrm{OH}$ concentrations ( $12 \mathrm{wt}$. $\mathrm{ppm} \mathrm{H}_{2} \mathrm{O}$ ) are observed in dunite PEL41 from Pello Hill and harzburgite LS11 from Lashaine.
Although both samples are coarse-granular, in the whole set of analyzed samples, there is no systematic correlation between olivine $\mathrm{OH}$ concentration and microstructure. There is also no correlation between the olivine $\mathrm{OH}$ concentration and $\mathrm{Mg \#}$ (Fig. 11). The homogeneity of $\mathrm{OH}$ concentrations in olivine was tested by analyses with 50 to $150 \mu \mathrm{m}$ step sizes along transects ( 850 to $3450 \mu \mathrm{m}$ long) on randomly oriented olivine grains in three samples: one mylonite from Pello Hill (PEL17), one garnet-bearing harzburgite from Lashaine (LS11), and one veinbearing sample from Pello Hill (PEL41). These profiles indicate homogeneous concentrations plateaus within grains, incompatible with significant dehydration (Thoraval and Demouchy, 2014).

Average orthopyroxene $\mathrm{OH}$ concentrations range between 97 and 212 wt. ppm $\mathrm{H}_{2} \mathrm{O}$ (Table 2), being in the range of concentrations reported by previous studies (Falus et al., 2008; Peslier, 2010; Peslier et al., 2002). In rift axis samples, orthopyroxene $\mathrm{OH}$ concentrations are more heterogeneous, but there is no systematic correlation between orthopyroxene $\mathrm{OH}$ concentration and xenolith locality or microstructure. Indeed, the lowest orthopyroxene $\mathrm{OH}$ concentrations are measured in mylonite 


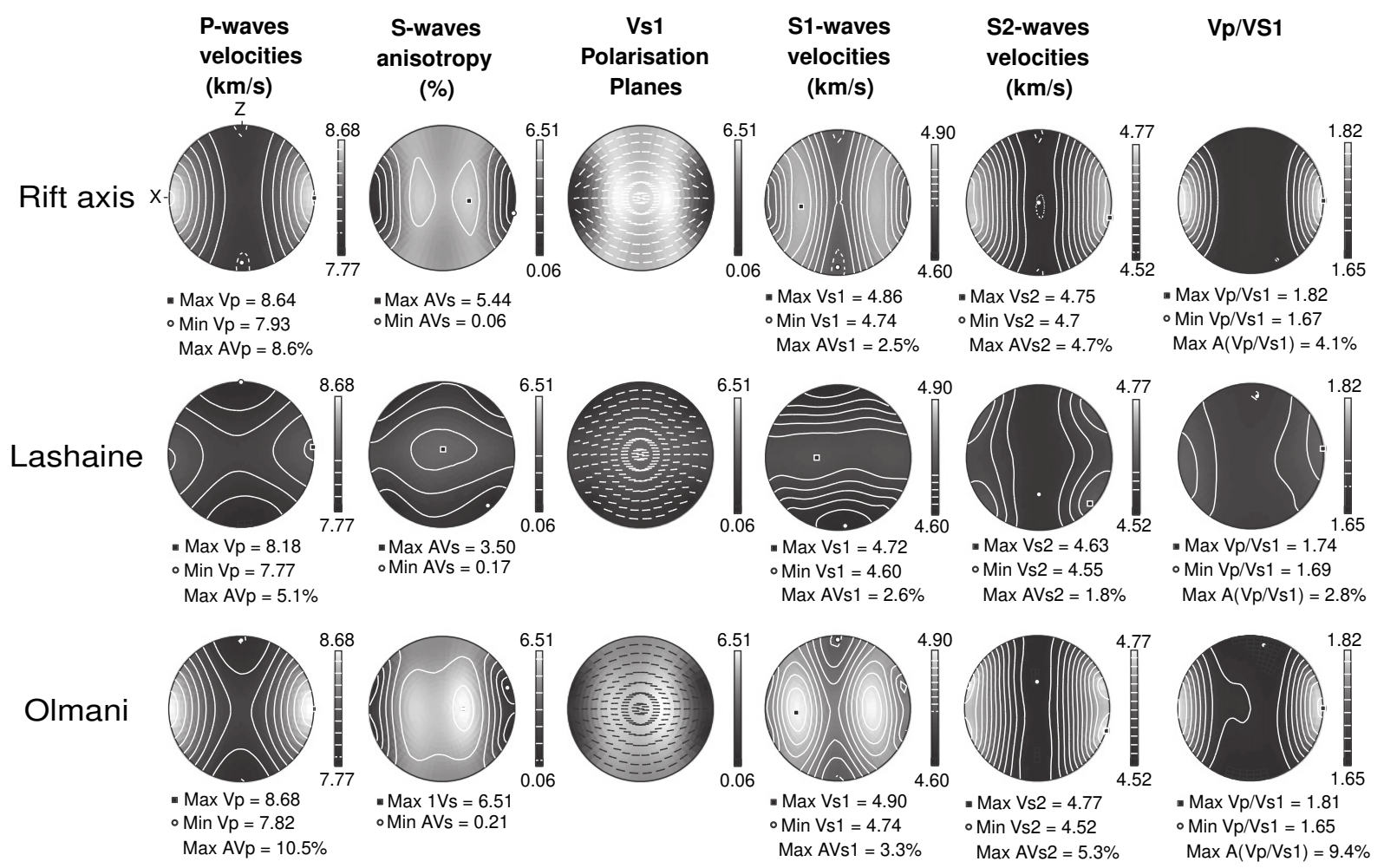

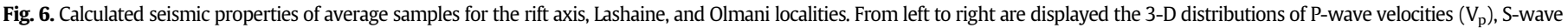

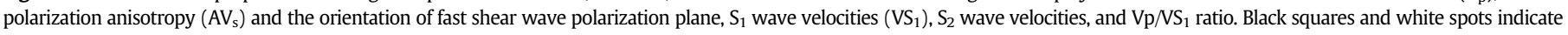
maximum and minimum values, respectively.

PEL17 and the highest, in mylonite PEL15. There is also no correlation between the olivine and orthopyroxene $\mathrm{OH}$ concentrations.

\section{Discussion}

\subsection{Thermomechanical and metasomatic evolution of North Tanzanian Divergence peridotites}

\subsubsection{Rift Axis (Pello Hill and Eledoi)}

The peridotites from the rift axis localities show a variety of microstructures, from mylonitic to porphyroclastic and coarse-granular. All exhibit evidence for plastic deformation and both dynamic and for static recrystallization, but the deformation conditions and the extent of static recrystallization vary from one sample to another. The obliquity between the lineation and subgrain boundaries in olivine suggests simple shear deformation in both porphyroclastic peridotites and mylonites, but the higher elongation of orthopyroxenes imply deformation under higher stresses in the mylonites. The heterogeneity in microstructures may indicate a spatial or a temporal variation of deformation conditions and intensity within the mantle below Eledoi and Pello Hill.

In both mylonites and porphyroclastic peridotites, the frequency and spacing between subgrain boundaries in olivine porphyroclasts and the extent of grain boundary polygonization vary from sample to sample (Fig. 3a and b). These microstructural features support a deformation followed by variable degree of annealing. The well-preserved intracrystalline deformation features in most porphyroclastic peridotites suggest, however, that the time span between the deformation and the extraction by the magma was too short to allow for complete annealing of the deformation microstructures. The recent character of the deformation is further supported by the rather high equilibration temperatures $\left(1050-1100{ }^{\circ} \mathrm{C}\right)$ recorded by these peridotites. The variable degree of annealing observed in these rocks may be explained by variable interaction with fluids or melts, by sampling of different depths, or by transient and spatially heterogeneous heating events.
Mylonites also record a temporal variation of deformation conditions. Highly stretched orthopyroxenes are a characteristic feature of the mylonites (Fig. 3a). Similar highly stretched orthopyroxenes have been described, in mylonitic peridotites from the Lanzo (Nicolas et al., 1972), Ronda (Soustelle et al., 2009; Tubìa et al., 2004), and Beni Bousera massifs (Frets et al., 2014), and were interpreted as the result of deformation under high stress at moderate temperature $\left(850-950{ }^{\circ} \mathrm{C}\right.$ estimated from thermobarometry in the peridotites and associated pyroxenites; Frets et al., 2014; Garrido et al., 2011). Closely spaced kinks in orthopyroxene also indicate deformation under high stress conditions. However, the stretched orthopyroxenes from the mylonites have indented shapes, with embayments filled by vein-like olivine crystals, which are often subparallel to the orthopyroxene elongation (Fig. 4a). In porphyroclastic peridotites, orthopyroxene embayments filled with olivine and olivine inclusions in orthopyroxene (Fig. 4c) are also present. These microstructures suggest reactions leading to consumption of orthopyroxene and crystallization of olivine. In both mylonites and porphyroclastic peridotites, the olivine crystals that replace orthopyroxene display ubiquituous undulose extinction and subgrain boundaries dominantly oriented normal to the crystals' elongation. This suggests that this reaction is synkinematic. Three processes may produce replacement of orthopyroxene by olivine: (1) incongruent melting of orthopyroxene (Kubo, 2002); (2) reaction between the peridotite and a Si-undersaturated melt (Kelemen, 1990; Kelemen et al., 1995), (3) percolation of aqueous fluids (Padrón-Navarta et al., 2010). The last process may occur at low temperatures $\left(650-700{ }^{\circ} \mathrm{C}\right)$, but implies very large volumes of aqueous fluids (Padrón-Navarta et al., 2010), which are plausible in a subduction zone, but not in a continental rift.

In summary, the recent deformation event recorded by the rift axis xenoliths started under high stress and probably low temperature. The deformation was later coupled with partial melting or reactive percolation of Si-undersaturated melts. Both processes imply high, near-solidus temperatures, which are at odds with the high stresses inferred in the 

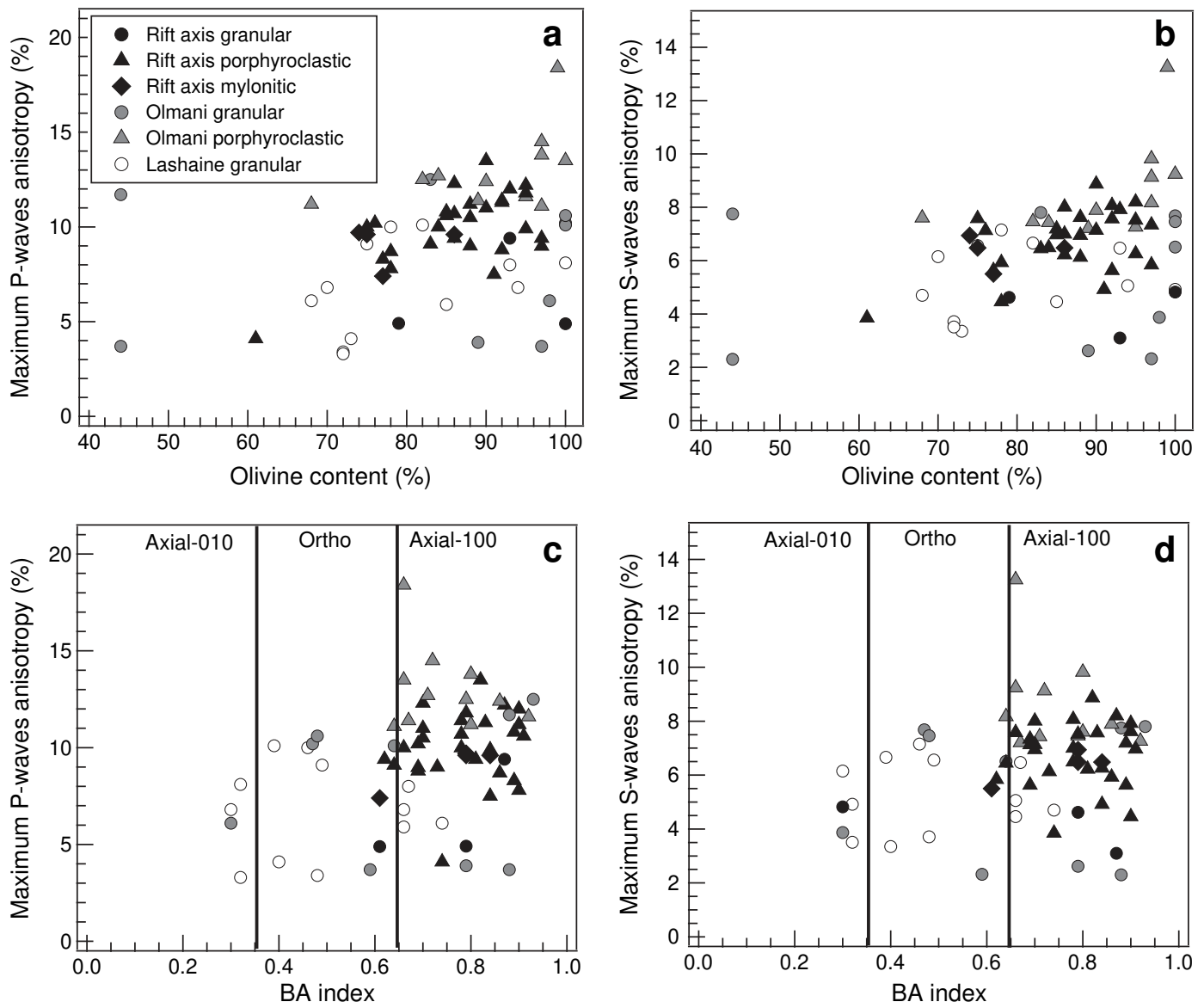

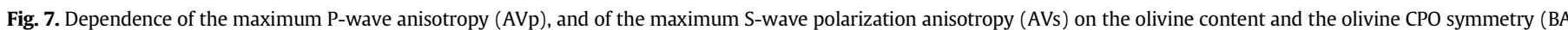
index).

mylonites from the stretching of orthopyroxenes. Moreover, the ubiquituous exsolutions seen in orthopyroxenes suggest significant cooling between this melt-assisted deformation and the extraction of the xenoliths. Together these observations imply transient and probably spatially heterogeneous temperature fields, marked by fast heating and cooling episodes, which probably accompanied deformation and reactive melt percolation (Kourim et al., in press; Kruckenberg et al., 2013). Interestingly, similar observations have been recently reported for peridotites samples from the boundary of the Middle Atlas (Marocco) in a context of progressive exhumation of the mantle lithosphere (El Messbahi et al., in press).

Coarse-grained dunites (EL14, PEL11, and PEL41) contain rare subgrain boundaries and common triple junctions (Fig. 3e). They display, however, a clear crystallographic fabric. Altogether this suggests that efficient annealing followed deformation by dislocation creep. Dunite may form when a harzburgite interacts with Si-undersaturated

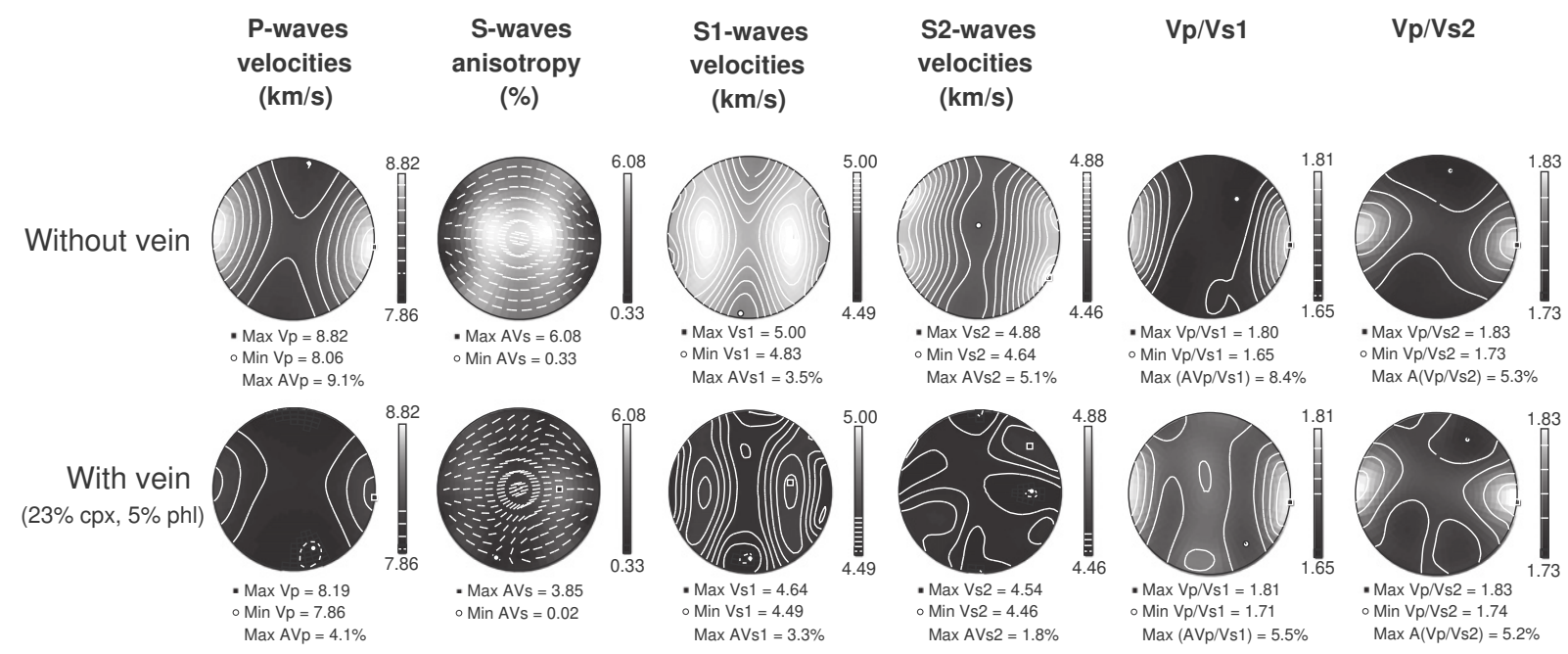

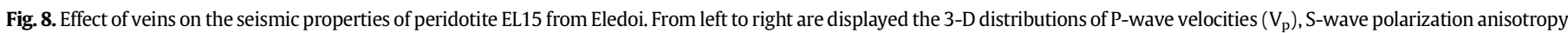
$\left(A V_{s}\right)$ and the orientation of fast shear wave polarization plane, $S_{1}$ wave velocities $\left(V_{1}\right), S_{2}$ wave velocities, and $V p / V S_{1}$ and $V p / V S_{2}$ ratios. 
melts (Berger, 1985; Berger and Vannier, 1984; Kelemen, 1990; Morgan and Liang, 2003). The coarse-grained dunites from Pello Hill and Eledoi contain olivines with significantly lower Mg\# (84-88, while the average for the other microstructures in these localities is $\sim 92$, Table 1 ). Such a strong enrichment in Fe suggests interaction with very large volumes of melts. The coarse-grained dunites might thus represent melt channels or melt accumulation levels within the mantle lithosphere (Berger, 1985; Berger and Vannier, 1984; Kelemen and Dick, 1995; Kelemen et al., 1995; Tommasi et al., 2004).

In mylonitic, porphyroclastic and coarse-granular peridotites, the well-defined olivine CPO indicates dislocation creep as the dominant deformation process. The olivine CPO patterns range from axial-[100] to orthorhombic. These olivine CPOs are consistent with deformation by simple or pure shear with dominant activation of (010)[100] or

a

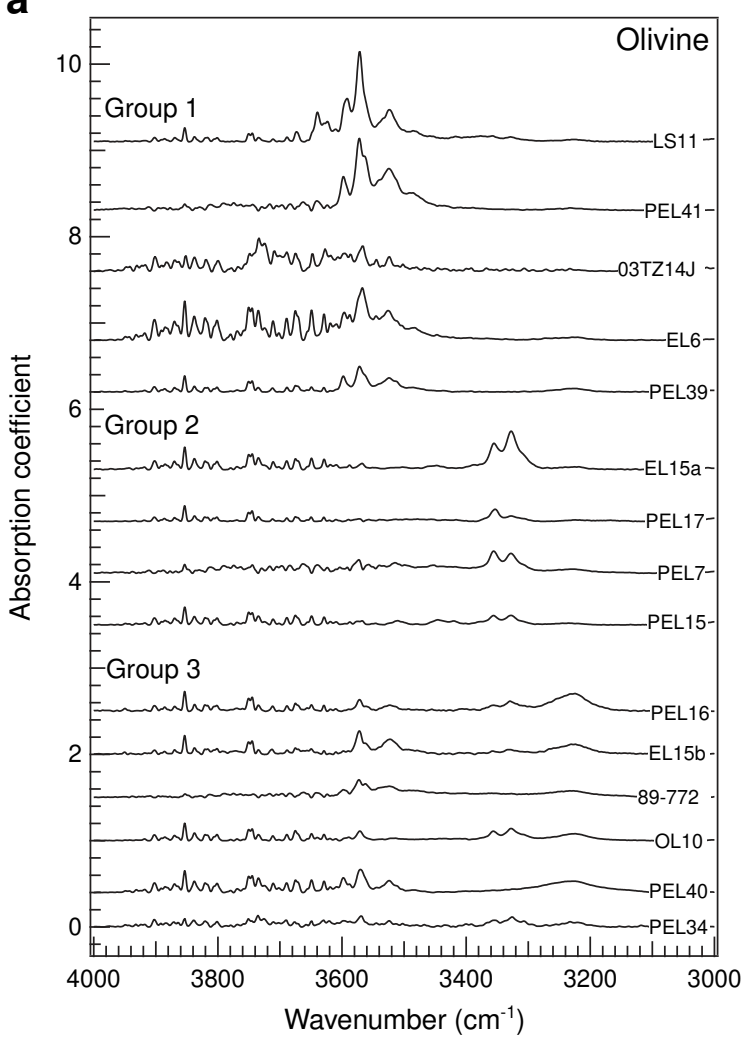

b

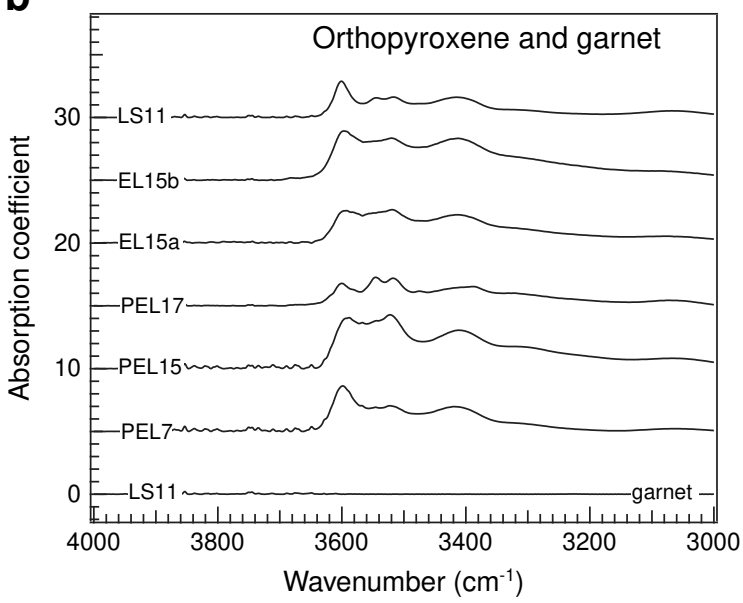

Fig. 9. Representative unpolarized FT infrared spectra of nominally anhydrous minerals in xenoliths from Tanzania. (a) Olivine; (b) orthopyroxene and garnet. All spectra are normalized to a sample thickness of $1 \mathrm{~cm}$. (0kl)[100] slip systems under high temperature, low pressure and anhydrous conditions (Tommasi et al., 1999, 2000). Axial-[100] CPO symmetry likely denotes a strain regime producing a well-defined stretching direction, such as transtension; Kruckenberg et al. (2014) have recently shown the correlation between axial-[100] CPO symmetry and prolate strain ellipsoids due to constructional deformation. Orthopyroxene CPOs indicate deformation by dislocation creep with activation of the [001] (100) slip system. They are always correlated to the olivine CPO, indicating that both minerals underwent the same deformation event.

In addition to the olivine-forming reactive melt percolation, textural evidence for metasomatism by hydrous melts has also been identified in many peridotites from Pello Hill and Eledoi. For instance, Dawson and Smith (1988) first analyzed the composition of the veins from Pello Hill mantle xenoliths and concluded that they bear asthenospheric $\mathrm{Nd}$ and $\mathrm{Sr}$ isotopic signatures and imparted REE, K, Fe, Ti metasomatism on the surrounding peridotite. It encompasses: (1) veins with diffuse margins that comprise clinopyroxene, amphibole, phlogopite, and spinel that crosscut deformation microstructures (Fig. 3d), (2) irregularlyshaped pockets of clinopyroxene, amphibole, phlogopite, and spinel (Fig. 4e). In these minerals, deformation substructures are uncommon. However, clinopyroxene crystals in veins do exhibit a clear CPO that is coherent with the $\mathrm{CPO}$ of olivine and orthopyroxene from the surrounding peridotite. Two hypotheses may explain this observation. First, vein intrusion may be synkinematic, but this hypothesis is at odds with the orientation of the veins that crosscut the foliation and with the lack of plastic deformation of the metasomatic phases. Thus, we propose that the vein intrusion was post-kinematic and the minerals crystallized in a preferential orientation controlled by the orientation of the preexisting orthopyroxene.

\subsubsection{Lashaine}

Mantle xenoliths from Lashaine mainly display very coarse-grained microstructures characterized by millimeter- to centimeter-sized grains with curvilinear, interpenetrating boundaries and low densities of subgrain boundaries (Figs. 3f and 4g). These observations point to efficient grain boundary migration. Together with the well-defined olivine and orthopyroxene CPOs, they support deformation by dislocation creep at high temperature and effective annealing. In LS9, the frequent olivine-orthopyroxene interpenetrating boundaries suggest reaction with percolating melts. In addition, the olivine tablets growing on other crystals (Fig. 4f) have been previously interpreted as resulting from fast grain growth in presence of fluids (Drury and Van Roermund, 1989).

Among the studied samples, the xenoliths from Lashaine are the only ones containing garnet, implying that deeper parts of the Tanzanian lithosphere have been sampled. Garnet crystals in peridotites LS4 and LS11 display interstitial shapes and usually rim orthopyroxene. This morphology led Gibson et al. (2013) to interpret these pyrope garnets as the product of exsolution from orthopyroxene due to cooling.

Well-defined olivine and orthopyroxene CPOs in Lashaine peridotites indicate that dislocation creep was the main deformation process. Orthopyroxene CPOs are consistent with deformation by dislocation creep with dominant activation of [001](100), as usually observed in deformed mantle peridotites and pyroxenites (e.g., Frets et al., 2012, 2014; Vauchez et al., 2005). Olivine CPO patterns are dominantly orthorhombic to axial-[010] (Fig. 5). Axial-[010] olivine CPO symmetry, though less common than orthorhombic and axial-[100] symmetries (Tommasi et al., 2000), has been described in many xenoliths suites from continental and oceanic environments (e.g., Bascou et al., 2008; Tommasi et al., 2008; Vauchez et al., 2005; Zaffarana et al., 2014) and in peridotite massifs (e.g., Frets et al., 2014; Soustelle et al., 2010). It may result from similar activation of [100](010) and [001](010) slip systems as a result of changes in physical parameters (e.g., olivine water contents, pressure, differential stresses, presence of melt) during deformation or from a deformation regime characterized by an oblate strain ellipsoid (Kruckenberg et al., 2014) such as pure shear or 
transpression (Tommasi et al., 1999). A dispersion of olivine [100] axes has also been observed in rocks undergoing dynamic and static recrystallization (Falus et al., 2011; Tommasi et al., 2008). Experiments on olivine single crystals and polycrystals have shown that [001]-glide is favored at low temperature and high differential stresses (Demouchy et al., 2009, 2013, 2014; Durham and Goetze, 1977; Phakey et al., 1972; Raleigh, 1968). However, this explanation is inconsistent with the very-coarse granular microstructures of Lashaine peridotites. The $\mathrm{OH}$ concentrations measured in olivine are too low $(<20 \mathrm{wt}$. ppm $\mathrm{H}_{2} \mathrm{O}$ ) to induce the transition from dominant [100] to dominant [001] glide suggested by Jung et al. (2006). Transition from [100] to [001] glide have also been observed as a result of increasing pressure in deformation experiments at high confining pressure (Couvy et al., 2004; Jung et al., 2006; Raterron et al., 2009). Occurrence of axial-[010] CPO in garnet-bearing harzburgite LS11 may suggest a change in dominant mechanism with increasing pressure, an interpretation similar to the one proposed by Vauchez et al. (2005) for the deepest Labait peridotites. However, this explanation cannot account for the common axial-[010] patterns in the Lashaine spinel peridotites. Deformation in presence of melt, accompanied by refertilization reactions, also results in development of axial-[010] olivine CPO (Higgie and Tommasi, 2012, 2014; Le Roux et al., 2008). Yet, there is no clear evidence for synkinematic refertilisation reactions in the studied peridotites. Thus axial-[010] olivine CPO in Lashaine peridotites probably results from either transpression or recrystallization. Transpression should also result in dispersion of orthopyroxene [001] axes in the foliation plane, but the small number of orthopyroxene crystals present in most samples does not allow corroborating or excluding this hypothesis. Evidence for static recrystallization and grain boundary migration is, on the other hand, widespread in these peridotites.

\subsubsection{Olmani}

Xenoliths from Olmani display microstructures and CPOs intermediate between those found in peridotites from rift-axis localities and from Lashaine (Figs. 3 and 7). Half of the Olmani samples display coarsegrained to very coarse-grained sizes, similar to the microstructures observed in Lashaine. The other half of Olmani samples exhibits coarseporphyroclastic to porphyroclastic microstructures, with characteristics similar to those observed in rift axis peridotites. All textural types from Olmani show evidence for olivine crystallization at the expenses of orthopyroxene. Chemical evidence for interaction with carbonatites was identified in several of the studied peridotites (89-772, 89-774, 89-776, and 89-773) by Rudnick et al. (1993). These samples display coarsegranular microstructures, suggesting that the carbonatitic metasomatism is not directly related to the recent deformation (probably rift-related), recorded by the porphyroclastic microstructures.

The well-defined olivine CPOs measured in Olmani peridotites suggests that dislocation creep was the main deformation process. All three olivine CPO symmetries are observed. Interestingly, Olmani granular peridotites tend to display axial-[010] olivine CPO, similar to those of the granular peridotites from Lashaine, whereas porphyroclastic to coarse-porphyroclastic samples show dominantly axial-[100] patterns, similar to rift axis peridotites. Moreover, the weak annealing observed in the porphyroclastic peridotites suggests that deformation occurred shortly before extraction. The orthopyroxene CPO is consistent with deformation by dislocation creep with dominant activation of [001](100) and $[001](010)$ slip systems. Olivine and orthopyroxene CPOs are always correlated, implying that they record the same deformation event.

A variation in microstructures and olivine $\mathrm{CPO}$ patterns between the localities of Olmani and Lashaine was not expected, as both localities are within the Tanzanian Divergence and distant of less than $30 \mathrm{~km}$. This variation may be explained by: (1) younger eruption ages in Olmani than Lashaine, in which case Olmani peridotites would record the recent deformation associated with the rifting, (2) a bias in xenolith sampling, (3) Olmani and Lashaine sample lithospheric domains with different tectonic ages, or (4) heteregeneous deformation of the lithospheric mantle at the scale of few tens of $\mathrm{km}$ within the transverse volcanic belt. The eruption age of Olmani and Lashaine is poorly constrained. However, neighboring volcanic centers with similar morphologies have eruption ages between 2.5 and 1.56 Ma (Evans et al., 1971; Le Gall et al., 2008; MacIntyre et al., 1974; Wilkinson et al., 1986). Hypothesis (1) is therefore improbable. A bias in xenolith sampling (2) cannot be definitely excluded, but is unlikely, since in spite of the large number of xenoliths collected, Lashaine xenoliths have very homogeneous microstructures. The presence of lithospheric domains of different ages (3) within the Mozambique belt is possible. Indeed, Lashaine and Olmani are located in a domain of the Mozambique belt that is interpreted as a remnant of cratonic lithosphere reworked during the Neoproterozoic Orogeny (Mansur et al., 2014; Möller et al., 1998). Similarities between Lashaine and cratonic peridotites are numerous. Rudnick et al. (1994) first highlighted similarities in mineral compositions between Lashaine and the Kaapvaal craton peridotites. Minimum ages of 3.4 and $2.9 \mathrm{Ga}$ were obtained from Re-Os studies of sulfides in mantle xenoliths from both Lashaine and Labait, a Quaternary volcano located on the eastern boundary of the Tanzanian craton (Fig. 1; Burton et al., 2000; Chesley et al., 1999). Comparison of the microstructures and the olivine CPOs of the Labait and Lashaine peridotites provides additional evidence for a common origin. Vauchez et al. (2005) described three textural types in the Labait peridotites, among which the garnet-free, coarse-grained peridotites display microstructures and olivine CPO very similar to those observed in the Lashaine peridotites. However, the similarities between Lashaine and Olmani coarse-granular peridotites make hypothesis (3) unlikely. Heterogeneous rift-related deformation within the volcanic belt is the most probable explanation to Lashaine and Olmani microstructural and CPO difference. Indeed, the deformation recorded by the Olmani porphyroclastic peridotites might be related to localized deformation in a strain transfer zone connecting the main rift to the Pangani Graben (Fig. 1) or to reactivation of the neoproterozoic Aswa shear zone (e.g., Corti et al., 2007; Ruotoistenmäki, 2014 and references therein) in a transtensional regime that resulted in the opening of the Pangani Graben.

\subsection{Hydration state of the Tanzanian lithosphere}

Diffusion data from experimentation and dehydration profiles from basalt-borne peridotite xenoliths point out to a very fast hydrogen ionic diffusion in olivine at high temperature (Mackwell and Kohlstedt, 1990; Demouchy and Mackwell, 2006; Demouchy et al., 2006; Peslier and Luhr, 2006; Denis et al., 2013). However, the homogeneity of $\mathrm{OH}$ concentrations along profiles in olivine in three samples suggests that the measured concentrations were not modified during xenolith extraction (Demouchy et al., 2006; Thoraval and Demouchy, 2014).

Average $\mathrm{OH}$ concentrations in olivine measured in the Tanzanian samples vary from very low to moderate (up to 12 wt. ppm $\mathrm{H}_{2} \mathrm{O}$; Fig. 10, Table 2). Average orthopyroxene $\mathrm{OH}$ concentrations range between 97 and 212 wt. ppm $\mathrm{H}_{2} \mathrm{O}$. In xenoliths from Pello Hill, the olivine $\mathrm{OH}$ concentrations are more heterogeneous than in those from Eledoi and Olmani. However, this difference might be related to the fact that we analyzed more samples from Pello Hill than from other localities. We also observe no clear relationship between the microstructure or the olivine $\mathrm{CPO}$ pattern and $\mathrm{OH}$ concentrations (Table 2, Fig. 10). We also do not observe significant differences in olivine $\mathrm{OH}$ concentrations between in- and off-axis samples (Fig. 10). The 2 samples that exhibit the highest $\mathrm{OH}$ concentrations in olivine are a garnet-bearing harzburgite LS11 from Lashaine and a vein-bearing dunite PEL41 from Pello Hill. We discuss below the potential origin of these relatively higher $\mathrm{OH}$ concentrations.

The harzburgitic to dunitic compositions and high olivine $\mathrm{Mg \#}$ in most samples suggest extensive partial melting, which might be as old as $3.4 \mathrm{Ga}$, based on Os isotopic dating of sulfides in a garnet lherzolite from Lashaine (Burton et al., 2000). Since $\mathrm{H}$ behaves as an incompatible 


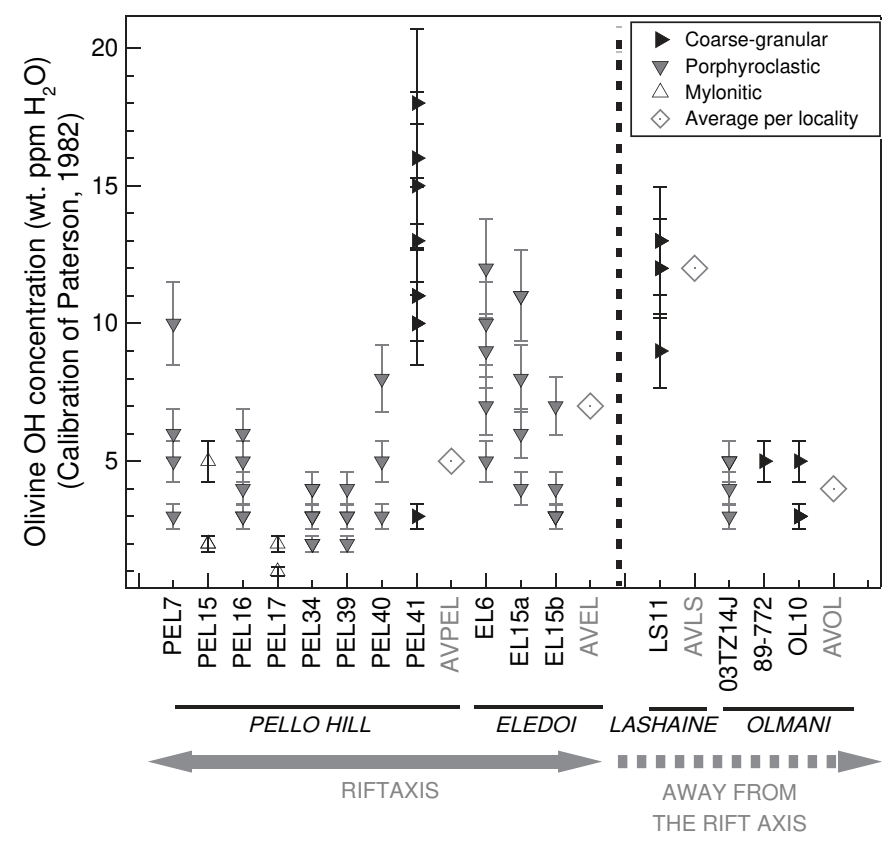

Fig. 10. $\mathrm{OH}$ concentrations in olivine in wt. ppm $\mathrm{H}_{2} \mathrm{O}$ (calibration of Paterson, 1982) as a function of xenolith provenance and texture.

element during partial melting (Bolfan-Casanova, 2005; Dixon et al., 2002; Hirschmann et al., 2005), olivine with high Mg\# should have the lowest $\mathrm{OH}$ concentrations. However, we observe no correlation between olivine Mg\# and $\mathrm{OH}$ concentrations (Fig. 11), implying that the Tanzanian samples were potentially hydrated or rehydrated during later metasomatic events.

Geochemical studies have provided evidence for multiple metasomatic events in mantle xenoliths from the sampled localities. Carbonatite metasomatism led to enrichment in REE, increase in Mg\#, and the crystallization of clinopyroxene and phosphate in Olmani xenoliths (Rudnick et al., 1993, 1994). However, this carbon-rich metasomatism should not result in extensive hydration of Nominally Anhydrous Minerals (NAM) because a high $\mathrm{CO}_{2}$ fugacity will lower $\mathrm{H}_{2} \mathrm{O}$ fugacity in the system and thus minimize the hydration of NAMs (Dixon et al., 1995; Sokol et al., 2010). In Lashaine peridotites, an episode of metasomatism, which

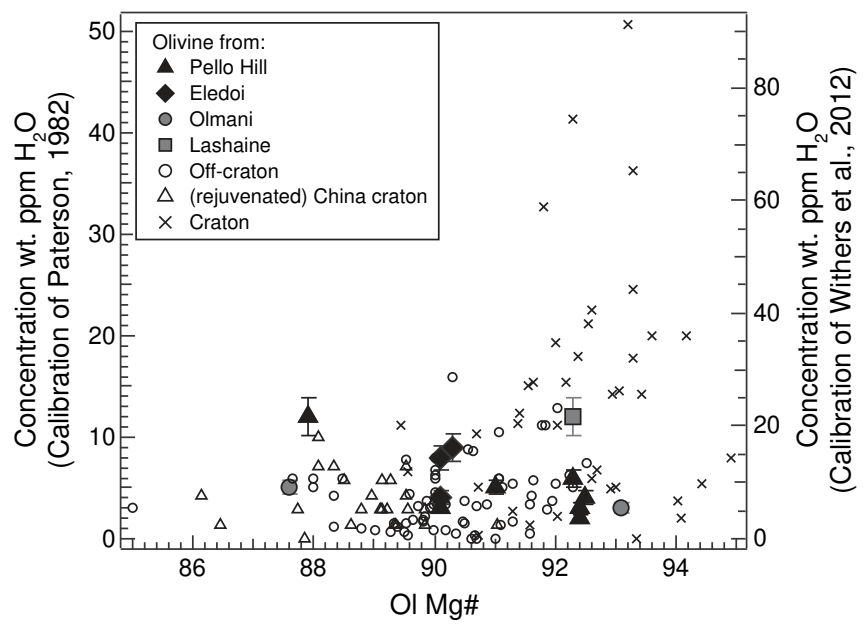

Fig. 11. OH concentrations in wt. ppm $\mathrm{H}_{2} \mathrm{O}$ (calibration of Paterson, 1982) versus $\mathrm{Mg \#}$ in olivine. For comparison, data obtained in previous studies on peridotite xenoliths from various localities are also shown as open symbols and crosses (Baptiste et al., 2012; Demouchy et al., 2006; Denis et al., 2013; Falus et al., 2008; Grant et al., 2007; Kurosawa et al., 1997; Matsyuk et al., 1998; Matsyuk and Langer, 2004; Peslier and Luhr, 2006; Peslier et al., 2008; Peslier et al., 2010; Yang et al., 2008). enriched the peridotites in $\mathrm{K}, \mathrm{Fe} \mathrm{Ca}$, $\mathrm{Ti}, \mathrm{Rb}$ and $\mathrm{REE}$, was dated at $\sim 2 \mathrm{Ga}$ based on Re-Os isotope data on sulfides (Burton et al., 2000; Dawson, 2002). A more recent metasomatism led to addition of $\mathrm{Si}, \mathrm{K}, \mathrm{Ti}, \mathrm{Ca}, \mathrm{Fe}$, $\mathrm{Nb}$, and Ta (Dawson, 2002). Rudnick et al. (1994) suggested that the $\mathrm{SiO}_{2}$ enrichment in Lashaine garnet peridotites was caused by the interaction with silicic melts derived from partial melting of a subducting slab, during the major subduction on the eastern edge of the Kaapvaal craton around 2 Gy ago (Möller et al., 1995). Such a process may modify the trace element contents of NAMs and allow for $\mathrm{OH}$ incorporation in olivine. It might therefore explain the relatively high $\mathrm{OH}$ concentration in olivine from garnet-bearing harzburgite LS11 (Fig. 10). Moreover, LS11 harzburgite is a garnet-bearing peridotite. Its deeper origin may also explain the higher $\mathrm{OH}$ concentration, since higher pressure implies higher water fugacity, favoring $\mathrm{OH}$ incorporation in olivine (Férot and Bolfan-Casanova, 2012; Kohlstedt et al., 1996).

The presence of undeformed hydrous phases in veins or diffuse pockets (Figs. 3d and 4d, e) in xenoliths from all sites implies extensive post-kinematic metasomatism by hydrous fluids or melts. Indeed, the vein-bearing dunite PEL41 from Pello Hill shows the highest OH concentrations in olivine from all analyzed samples (Fig. 10). However, measurement of the $\mathrm{OH}$ concentration in olivine at different distances from the veins in dunite PEL41 shows no systematic increase in olivine $\mathrm{OH}$ concentrations in the vicinity of the vein (Fig. 12). Similar measurements were performed for samples EL15 and PEL40. These data suggest that hydration of olivine is not related to the metasomatic event that formed the veins. The actual nature of the metasomatic agent and the timing of the hydration of olivine remain therefore undetermined.

\subsection{Upper mantle deformation and seismic anisotropy in the North Tanzanian Divergence}

Microstructures and CPO analysis of the Tanzanian xenoliths show that the lithospheric mantle in the Northern Tanzanian Divergence is pervasively deformed. However, the strong heterogeneity in microstructures and olivine CPO suggests that this deformation was acquired during multiple tectonic events, probably separated by quiescence episodes, which allowed for annealing. The observed microstructural heterogeneity could also be explained by spatial variations in strain rate. The mylonitic to granular microstructures of the rift axis peridotites, despite rather high equilibrium temperatures, underwent limited annealing, which suggests that they were deformed shortly before extraction. Therefore, these samples likely record the deformation associated with the rift propagation in this region. Among the peridotites

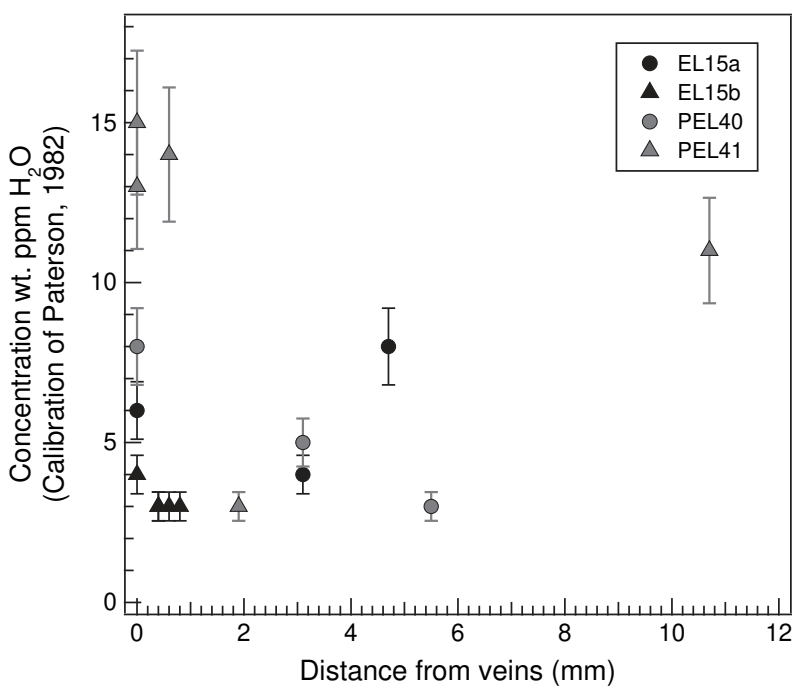

Fig. 12. Olivine $\mathrm{OH}$ concentrations in wt. ppm $\mathrm{H}_{2} \mathrm{O}$, (calibration of Paterson, 1982) as a function of the distance from hydrous mineral-rich veins. 
from the rift axis, the most common olivine CPO pattern is the axial-[100] pattern. This pattern implies that: (1) [100] is the dominant glide direction in olivine and (2) the active deformation regime has a well-defined stretching direction. Numerical models show that development of axial[100] olivine CPO is characteristic of transtensional deformation regimes (Tommasi et al., 1999). High temperature $\left(1200^{\circ} \mathrm{C}\right)$, high strain rate $\left(<10^{-6} \mathrm{~s}^{-1}\right)$ torsion experiments in dry olivine aggregates (Bystricky et al., 2000; Hansen et al., 2014) have shown, however, that [100]-axial CPO also forms during the initial stages of simple shear deformation, with a progressive transition from axial-[100] symmetry to orthorhombic symmetry for $\gamma>5$. The obliquity between subgrain boundaries and the foliation observed in the mylonites and porphyroclastic peridotites are consistent with a simple shear component of deformation. However, the extreme stretching of the pyroxenes in the mylonites (Figs. 3a and 4a) implies high finite strains. Altogether, these observations support that the deformation, which developed the mylonites and porphyroclastic peridotites in the mantle lithosphere beneath the southern part of the East-African rift, results from a transtensional strain regime with a strong simple shear component.

Comparison between the seismic properties of the studied xenoliths and seismological data may help to further constrain the deformation regime in the region. Anisotropy measurements in the Tanzania Divergence show fast SKS polarization directions parallel or slightly oblique to the rift axis (Albaric et al., 2014; Bagley and Nyblade, 2013; Gao et al., 1997; Walker et al., 2004). Oblique fast polarization directions for teleseismic shear waves are expected for a rift formed by transtensional deformation of the lithosphere, which should result in axial-[100] olivine CPO patterns with a concentration of olivine [100] axes close to horizontal and slightly oblique to the rift axis (Vauchez et al., 2000). These data, together with the predominance of axial[100] olivine CPO in the studied mantle xenoliths from Pello Hill and Eledoi, are in good agreement with the suggestion that the East African Rift was initiated by a transtensional reactivation of inherited crystallographic fabrics, as suggested by Tommasi and Vauchez (2001) and Tommasi et al. (2009) who showed, using numerical models, that a CPO-induced mechanical anisotropy in the mantle imposes deformation with a strong strike-slip component parallel to the reactivated mantle structure.

Away from the rift axis, the coarse-granular, highly annealed microstructures of the Lashaine peridotites probably record an older deformation event. The olivine CPO in these peridotites also differs markedly from those from the rift axis: axial-[010] to orthorhombic patterns predominate. The deformation microstructures and CPOs frozen in these peridotites might be related to the last major compressive event in the region: the formation of the Mozambique Belt during the Neoproterozoic East African Orogeny (e.g., Pinna et al., 1993). Considering the similarity in microstructure and composition between the xenoliths from Lashaine, Labait (Vauchez et al., 2005), and the Kaapvaal craton (Baptiste et al., 2012), it may also be hypothesized that the lithosphere beneath Lashaine is a remnant of a cratonic domain embedded and preserved in the Mozambique Belt, as suggested by Gibson et al. (2013) based on the geochemical study of ultra-depleted garnets. In this case, the structures and CPO of Lashaine xenoliths might result from even older deformations, such as those recorded in the neighboring Tanzanian craton (e.g., Bagley and Nyblade, 2013; Walker et al., 2004). Although localized within the transverse volcanic belt, the Olmani mantle xenoliths show both types of microstructures and CPOs: rift-axis or Lashaine ones. This might result from localized deformation reworking an older lithosphere (similar to the Lashaine mantle, or affected by the Aswa transcurrent shear zone) leading to the development of a subordinate branch of the East African Rift southeast of Mount Kilimandjaro (see Fig. 1).

The present study shows that lithospheric mantle beneath the southern part of the East African Rift is anisotropic. Below the rift axis, calculated seismic anisotropy intensities (Fig. 7, Table 1) range between 3.3 and $18.4 \%$ for P-waves, and between 2.3 and $13.3 \%$ for S-waves. The contribution of the mantle lithosphere cannot therefore be neglected in the interpretation of shear wave splitting data, even if the coherence of the large-scale seismic anisotropy pattern has lead investigators to favor a sublithospheric flow interpretation (e.g., Bagley and Nyblade, 2013). Estimates of the crustal and lithospheric thicknesses in this region vary between 36-44 km and 100-150 km (Dugda et al., 2009; Julià et al., 2005), respectively. Upper mantle S-wave velocities of $4.6 \mathrm{~km} / \mathrm{s}$ were measured in the region (Julià et al., 2005). Assuming that the rift formed by transtension, we expect the foliation to be near vertical and the lineation close to horizontal and slightly oblique to the rift axis (Vauchez et al., 2000). SKS-waves will then sample the maximum S-wave polarization anisotropy (Y direction in Fig. 6), leading to delay times around $0.65 \mathrm{~s}$ for a $60 \mathrm{~km}$-thick mantle, and of $1.2 \mathrm{~s}$ for a $110 \mathrm{~km}$-thick mantle. In the North Tanzanian Divergence, Walker et al. (2004) measured SKS delay times of 0.3-0.8 s, while Bagley and Nyblade (2013) and Albaric et al. (2014) obtained mean delay times of 0.7 and $1.2 \mathrm{~s}$, respectively. Therefore, the anisotropy induced by olivine CPOs in the Tanzanian peridotites can explain the SKS delay times measured in the region. Within the main Ethiopian rift, SKS studies also report polarization directions subparallel to the rift trend and variable delay times (0.5-1.7 s: Gashawbeza et al., 2004; 1-3 s: Kendall et al., 2005). However, SKS splitting delay times as high as those reported by Kendall et al. (2005) in the Afars cannot be explained by the anisotropies recorded in Tanzanian xenoliths, in agreement with the interpretation that they reflect the presence of oriented melt pockets (Ayele et al., 2004; Bastow et al., 2010; Hammond et al., 2014; Kendall et al., 2005; Sicilia et al., 2008).

\section{Conclusions}

Xenoliths sampling the lithospheric mantle beneath the North Tanzanian Divergence in the East African Rift display a high variability in microstructures and olivine CPO depending on their location. Beneath the rift-axis and Olmani, within the volcanic transverse belt, the occurrence of mylonitic to porphyroclastic microstructures suggests recent deformation. Variable microstructures and grain sizes in these rocks suggest lateral and/or vertical variation of the deformation conditions within the mantle, as well as variable degrees of annealing, that may be related to variable interaction with fluids or melts, or to different time spans between deformation and xenolith extraction. The presence of mylonites point to strain localization, but there is no evidence of dominant grain boundary sliding in any of the studied rocks: the ubiquitous dislocation-related intracrystalline deformation features in olivine and orthopyroxene and the strong axial-[100] olivine CPO point to dislocation creep with dominant activation of the [100](010) slip system. The mylonites also record evidence for marked changes in temperature, probably due to transient heating events. Highly stretched orthopyroxene crystals in mylonites from rift axis localities suggest that the deformation initiated under high stress and probably low/moderate temperature conditions, but the evidence of synkinematic olivine crystallization at the expenses of orthopyroxene observed in both mylonitic and porphyroclastic peridotites from rift axis localities and Olmani indicate that deformation continued in the presence of melt, under near-solidus conditions. Finally, ubiquitous exsolutions in orthopyroxene in the mylonites suggest significant cooling between this melt-assisted deformation and the xenoliths extraction. Late, postkinematic metasomatism by hydrous melts is evidenced by the occurrence of veins crosscutting the microstructure, as well as the presence of interstitial clinopyroxene and phlogopite in rift axis peridotites.

In the volcanic transverse belt, the coarse-granular microstructures and well-defined CPOs that characterize the Lashaine and part of the Olmani peridotites likely result from an older deformation event. The well-defined axial-[010] to orthorhombic CPO patterns in these peridotites may be associated with the formation of the Mozambique Belt or with an even older event. Finally, the variability of microstructures and CPOs in Olmani peridotites, which are either Lashaine-like or rift-axis-like, may indicate a heterogeneous deformation within the 
volcanic transverse belt, probably related to localized deformation associated to the development of the Pangani Graben through transtensional reactivation of the Aswa shear zone (Fig. 1).

Tanzanian xenoliths are variably hydrated $(\mathrm{OH}$ contents in olivine vary between 2 and 18 ppm $\mathrm{H}_{2} \mathrm{O}$ wt., Paterson calibration), but olivine $\mathrm{OH}$ concentrations do not vary systematically neither between in- and off-axis samples, nor as a function of the microstructure or CPO patterns. Occurrence of $\mathrm{OH}$ in olivines with high $\mathrm{Mg} \#$ implies hydration by metasomatism after partial melting. However, the lack of spatial correlation between $\mathrm{OH}$ contents in olivine and the veins containing hydrous phases, implies that the olivine hydration is not directly due to the vein-forming metasomatism.

Maximum $P$ wave azimuthal anisotropy $(A V p)$ ranges between 3.3 and $18.4 \%$ and the maximum $S$ wave polarization anisotropy (AVs), between 2.3 and $13.2 \%$. The change in olivine CPO symmetry from a locality to another results in a variation in the seismic anisotropy patterns. Comparison between olivine CPOs and polarization direction of the fast SKS wave is consistent with a rift formed by a transtensional deformation involving reactivation of inherited tectonic fabric.

Supplementary data to this article can be found online at http://dx. doi.org/10.1016/j.tecto.2014.11.011.

\section{Acknowledgments}

Julien Baticle is thanked for analyzing several thin sections with the EBSD and Philippe Nonnotte for lending several mantle xenoliths from his collection. W. Behr and an anonymous reviewer are thanked for their constructive reviews. D. Mainprice provided the programs for treating the CPO data and calculating seismic properties. C. Nevado and D. Delmas prepared high-quality polished thin sections for FTIR and EBSD measurements. EBSD measurements were performed with the help of F. Barou at the EBSD-SEM national facility at Geosciences Montpellier. Electron microprobe analyses were carried out with the help of C. Merlet at the Service Microsonde Sud, Montpellier University. FTIR analyses were performed with the assistance of D. Maurin at the Lab. Colloids, Verre et Nanomateriaux, at Montpellier University, France.

\section{References}

Abramson, E.H., Brown, J.M., Slutsky, L.J., Zaug, J., 1997. The elastic constants of San Carlos olivine to 17 GPa. J. Geophys. Res. 102 (B6), 12,253-12,263.

Albaric, J., Perrot, J., Déverchère, J., Deschamps, A., Le Gall, B., Ferdinand, R.W., Petit, C., Tiberi, C., Sue, C., Songo, M., 2010. Contrasted seismogenic and rheological behaviours from shallow and deep earthquake sequence in the North Tanzanian Divergence, East Africa. J. Afr. Earth Sci. 58 (5), 799-811.

Albaric, J., Déverchère, J., Perrot, J., Jakovlev, A., Deschamps, A., 2014. Deep crustal earthquakes in North Tanzania, East Africa: interplay between tectonic and magmatic processes in an incipient rift. Geochem. Geophys. Geosyst. 15 (2), 374-394.

Ayele, A., Stuart, G.W., Kendall, J.-M., 2004. Insights into rifting from shear wave splitting and receiver functions: an example from Ethiopia. Geophys. J. Int. 157, 354-362.

Bagley, B., Nyblade, A., 2013. Seismic anisotropy in eastern Africa, mantle flow, and the African superplume. Geophys. Res. Lett. 40, 1500-1505.

Baptiste, V., Tommasi, A., Demouchy, S., 2012. Deformation and hydration of the lithospheric mantle beneath the Kaapvaal craton, South Africa. Lithos 149, 31-50.

Bascou, J., Delpech, G., Vauchez, A., Moine, B.N., Cottin, J.Y., Barruol, G., 2008. An integrated study of microstructural, geochemical, and seismic properties of the lithospheric mantle above the Kerguelen plume (Indian Ocean). Geochem. Geophys. Geosyst. 9 (4), 1-26

Bastow, I.D., Pilidou, S., Kendall, J.-M., Stuart, G.W., 2010. Melt-induced seismic anisotropy and magma assisted rifting in Ethiopia: evidence from surface waves. Geochem. Geophys. Geosyst. 11 (6), Q0AB05.

Ben Ismaïl, W., Mainprice, D., 1998. An olivine fabric database: an overview of upper mantle fabrics and seismic anisotropy. Tectonophysics 296 (1-2), 145-157.

Berger, E.T. 1985. Petrographic heterogeneities of the South Pacific mantle below the Austral archipelago: evidence and interpretation using ultramafic investigations. Bull. Soc. Geol. Fr. 1, 207-216.

Berger, E.T., Vannier, M., 1984. Les dunites en enclaves dans les basaltes alcalins des îles océaniques: approche pétrologique. Bull. Mineral. 107, 649-663.

Berry, A.J., Hermann, J., O'Neill, H.S.C., Foran, G.J., 2005. Fingerprinting the water site in mantle olivine. Geology 33 (11), 869-872.

Berry, A.J., O'Neill, H.S.C., Hermann, J., Scott, D.R., 2007. The infrared signature of water associated with trivalent cations in olivine. Earth Planet. Sci. Lett. 261 (1-2), 134-142.
Bezacier, L., Reynard, B., Bass, J.D., Wang, J., Mainprice, D., 2010. Elasticity of glaucophane, seismic velocities and anisotropy of the subducted oceanic crust. Tectonophysics 494 (3-4), 201-210.

Bolfan-Casanova, N., 2005. Water in the Earth's mantle. Mineral. Mag. 69 (3), 229-257.

Brey, G.P., Köhler, T., 1990. Geothermobarometry in four-phase lherzolites II. New thermobarometers, and practical assessment of existing thermobarometers. J. Petrol. 31 (6), 1353-1378.

Buck, W.R., 2006. The role of magma in the development of the Afro-Arabian Rift System. Geol. Soc. Lond., Spec. Publ. 259, 43-54.

Bunge, H.J., 1982. Texture Analysis in Materials Sciences. Buttleworth, London (593 pp.).

Burton, K.W., et al., 2000. The distribution and behaviour of rhenium and osmium amongst mantle minerals and the age of the lithospheric mantle beneath Tanzania. Earth Planet. Sci. Lett. 183, 93-106.

Bystricky, M., Kunze, K., Burlini, L., Burg, J.-P., 2000. High shear strain in olivine agreggates: rheological and seismic consequences. Science 290, 1564-1567.

Cerling, T.E., Powers, D.W., 1977. Paleorifting between the Gregory and the Ethiopian rifts. Geology 5, 441-444.

Chai, M., Brown, J.M., Slutsky, L.J., 1997a. The elastic constants of pyrope-grossularalmandine garnets to 20 GPa. Geophys. Res. Lett. 24 (4), 523-526.

Chai, M., Brown, J.M., Slutsky, L.J., 1997b. The elastic constants of an aluminous orthopyroxene to 12.5 GPa. J. Geophys. Res. 102 (B7), 14,779-14,785.

Chesley, J.T., Rudnick, R.L., Lee, C.-T., 1999. Re-Os systematics of mantle xenoliths from the East African Rift: age, structure, and history of the Tanzanian craton. Geochim. Cosmochim. Acta 63, 1203-1217.

Collins, M.D., Brown, J.M., 1998. Elasticity of an upper mantle clinopyroxene. Phys. Chem. Miner. 26, 7-13.

Corti, G., van Wijk, J., Cloetingh, S., Morley, C.K., 2007. Tectonic inheritance and continental rift architecture: numerical and analogue models of the East African Rift system. Tectonics 26, TC6006.

Couvy, H., et al., 2004. Shear deformation experiments of forsterite at $11 \mathrm{GPa}-1400{ }^{\circ} \mathrm{C}$ in the multianvil apparatus. Eur. J. Mineral. 16 (6), 877-889.

Crossley, R., Knight, R.M., 1981. Volcanism in the western part of the Rift valley in Southern Kenya. Bull. Volcanol. 44, 117-128.

Dawson, J.B., 2002. Metasomatism and partial melting in the upper-mantle peridotite xenoliths from the Lashaine Volcano, Northern Tanzania. J. Petrol. 43 (9), 1749-1777.

Dawson, J.B., Smith, J.V., 1988. Metasomatised and veined upper-mantle xenoliths from Pello Hill, Tanzania: evidence for anomalously-light mantle beneath the Tanzanian sector of the East African Rift Valley. Contrib. Mineral. Petrol. 100, 510-527.

Demouchy, S., Mackwell, S., 2006. Mechanisms of hydrogen incorporation and diffusion in iron-bearing olivine. Physics and Chemistry of Minerals 33, 347-355.

Demouchy, S., Jacobsen, S.D., Gaillard, F., Stern, C.R., 2006. Rapid magma ascent recorded by water diffusion profiles in mantle olivine. Geology 34 (6), 429-432.

Demouchy, S., Schneider, S.E., Mackwell, S.J., Zimmerman, M.E., Kohlstedt, D.L., 2009. Experimental deformation of olivine single crystals at lithospheric temperatures. Geophys. Res. Lett. 36 (4), 1-5.

Demouchy, S., Tommasi, A., Boffa-Ballaran, T., Cordier, P., 2013. Low strength of Earth's uppermost mantle inferred from tri-axial deformation experiments on dry olivine crystals. Phys. Earth Planet. Inter. 220 (37-49).

Demouchy, S., Mussi, A., Barou, F., Tommasi, A., Cordier, P., 2014. Viscoplasticity of polycrystalline olivine at high pressure and $900{ }^{\circ} \mathrm{C}$. Tectonophysics 623, 123-135.

Denis, C.M., Demouchy, S., Shaw, C.S., 2013. Evidence of dehydration in peridotites from Eifel Volcanic Field and estimates of the rate of magma ascent. J. Volcanol. Geotherm. Res. 258, 85-99.

Dijkstra, A.H., Drury, M.R., Vissers, R.L.M., Newman, J., 2002. On the role of melt-rock reaction in mantle shear zone formation in the Othris Peridotite Massif (Greece). Journal of Structural Geology 24, 1431-1450.

Dixon, J.E., Stolper, E.M., Holloway, J.R., 1995. An experimental study of water and carbon dioxide solubilities in mid-ocean ridge basaltic liquids. Part I: calibration and solubility models. J. Petrol. 36 (6), 1607-1631.

Dixon, J.E., Leist, L., Langmuir, C., Schilling, J.-G., 2002. Recycled dehydrated lithosphere observed in plume-influenced mid-ocean-ridge basalt. Nature 420 (6914), 385-389.

Drury, M.R., Van Roermund, H.L.M., 1989. Fluid assisted recrystallization in upper mantle peridotite xenoliths from kimberlites. J. Petrol. 30, 133-152.

Dugda, M.T., Nyblade, A., Julià, J., 2007. Thin lithosphere beneath the Ethiopian Plateau revealed by a joint inversion of Rayleigh wave group velocities and receiver functions. J. Geophys. Res. 112, B08305.

Dugda, M.T., Nyblade, A., Julià, J., 2009. S-wave velocity structure of the crust and upper mantle beneath Kenya in comparison to Tanzania and Ethiopia: implications for the formation of the East African and Ethiopian Plateaus. S. Afr. J. Geol. 112, 241-250.

Dunbar, J.A., Sawyer, D.S., 1989. How preexisting weaknesses control the styles of continental breakup. J. Geophys. Res. 94, 7278-7292.

Durham, W.B., Goetze, C., 1977. Plastic flow of oriented single crystals of olivine 1. Mechanical data. J. Geophys. Res. (82), 5737-5754.

El Messbahi, H., Bodinier, J.-L., Vauchez, A., Dautria, J.-M., Ouali, H., Garrido, C.J., 2014. Short wavelength lateral variability of lithospheric mantle beneath the Middle Atlas (Morocco) as recorded by mantle xenoliths. Tectonophysics http://dx.doi.org/10. 1016/j.tecto.2014.11.020 (in press)

Evans, A.L., Fairhead, J.D., Mitchell, J.G., 1971. Potassium-argon ages from the volcanic province of Northern Tanzania. Nature 229, 19-20.

Fabriès, J., 1979. Spinel-olivine geothermometry in peridotites from ultramafic complexes. Contrib. Mineral. Petrol. 69, 329-336.

Falus, G., Tommasi, A., Ingrin, J., Csaba, S., 2008. Deformation and seismic anisotropy of the lithospheric mantle in the southeastern Carpathians as inferred from the study of mantle xenoliths. Earth Planet. Sci. Lett. 272, 50-64. http://dx.doi.org/10.1016/j.epsl. 2008.04.035. 
Falus, G., Tommasi, A., Soustelle, V., 2011. Effect of dynamic recrystallization on olivine crystal preferred orientations in mantle xenoliths deformed under varied stress conditions. J. Struct. Geol. 33, 1528-1540.

Férot, A., Bolfan-Casanova, N., 2012. Water storage capacity in olivine and pyroxene to 14 GPa: implications for the water content of the Earth's upper mantle and nature of seismic discontinuities. Earth Planet. Sci. Lett. 349-350, 218-230.

Frets, E., Tommasi, A., Garrido, C.J., Padron-Navarta, J.A., Amri, I., Targuisti, K., 2012. Deformation processes and rheology of pyroxenites deformed under lithospheric mantle conditions. J. Struct. Geol. 39, 138-157. http://dx.doi.org/10.1016/j.jsg.2012.02.019.

Frets, E.C., Tommasi, A., Garrido, C.J., Vauchez, A., Mainprice, D., Targuisti, K., Amri, I., 2014. The Beni Bousera Peridotite (Rift Belt, Morocco): an oblique-slip low angle shear zone thinning the subcontinental mantle lithosphere. J. Petrol. 55 (2), 283-313.

Gao, S., et al., 1997. SKS splitting beneath continental rift zones. J. Geophys. Res. 102 (B10), 22781-22797.

Garrido, C.J., Gueydan, F., Booth-Rea, G., Précigout, J., Hidas, K., Padrón-Navarta, J.A. Marchesi, C., 2011. Garnet lherzolite and garnet-spinel mylonite in the Ronda peridotite: vestiges of Oligocene backarc mantle lithospheric extension in the western Mediterranean. Geology 39, 927-930.

Gashawbeza, E.M., Klemperer, S.L., Nyblade, A.A., Walker, K.T., Keranen, K.M., 2004. Shearwave splitting in Ethiopia: Precambrian mantle anisotropy locally modified by Neogene rifting. Geophys. Res. Lett. 31, 1-4.

Gibson, S.A., McMahon, S.C., Day, J.A., Dawson, J.B., 2013. Highly refractory lithospheric mantle beneath the Tanzanian Craton: evidence from Lashaine pre-metasomatic garnet-bearing peridotites. J. Petrol. 54, 1503-1546.

Grant, K., Ingrin, J., Lorand, J., Dumas, P., 2007. Water partitioning between mantle minerals from peridotite xenoliths. Contrib. Mineral. Petrol. 154 (1), 15-34.

Hammond, J.O.S., Kendall, J.-M., Wookey, J., Stuart, G.W., Keir, D., Ayele, A., 2014. Differentiating flow, melt, or fossil seismic anisotropy beneath Ethiopia. Geochem. Geophys. Geosyst. 15, 1878-1894.

Hansen, S., Zhao, Y., Zimmerman, M.E., Kohlstedt, D.L., 2014. Protracted fabric evolution in olivine: implications for the relationship among strain, crystallographic fabric, and seismic anisotropy. Earth Planet. Sci. Lett. 387, 157-168.

Hielscher, R., Schaeben, H., 2008. A novel pole figure inversion method: specification of the MTEX algorithm. J. Appl. Crystallogr. 41, 1024-1037.

Higgie, K., Tommasi, A., 2012. Feedbacks between deformation and melt distribution in the crust-mantle transition zone of the Oman ophiolite. Earth Planet. Sci. Lett. 359-360, 61-72.

Higgie, K., Tommasi, A., 2014. Deformation in a partially molten mantle: constraints from plagioclase-lherzolites from Lanzo, western Alps. Tectonophysics 615-616, 167-181.

Hirschmann, M.M., Aubaud, C., Withers, A.C., 2005. Storage capacity of $\mathrm{H}_{2} \mathrm{O}$ in nominally anhydrous minerals in the upper mantle. Earth Planet. Sci. Lett. 236 (1-2), 167-181.

Hirth, G., Kohlstedt, D., 2003. Rheology of the upper mantle and the mantle wedge: a view from the experimentalists. Geophysical Monograph 138, 83-105.

Julià, J., Ammon, C.J., Nyblade, A., 2005. Evidence for mafic lower crust in Tanzania, East Africa, from joint inversion of receiver functions and Rayleigh wave dispersion velocities. Geophys. J. Int. 162, 555-569.

Jung, H., Katayama, I., Jiang, Z., Hiraga, T., Karato, S., 2006. Effect of water and stress on the lattice-preferred orientation of olivine. Tectonophysics 421 (1-2), 1-22.

Kelemen, P.B., 1990. Reaction between ultramafic rock and fractionating basaltic magma I. Phase relations, the origin of calc-alkaline magma series, and the formation of discordant dunite. J. Petrol. 31 (1), 51-98.

Kelemen, P.B., Dick, H.J.B., 1995. Focused melt flow and localized deformation in the upper-mantle juxtaposition of replacive dunite and ductile shear zones in the josephine peridotite, SW oregon. J. Geophys. Res. 100 (B1), 423-438.

Kelemen, P.B., Shimizu, N., Salters, V.J.M., 1995. Extraction of mid-ocean-ridge basalt from the upwelling mantle by focused flow of melt in dunite channels. Nature 375 , 747-753.

Kendall, J.-M., Stuart, G.W., Ebinger, C., Bastow, I.D., Keir, D., 2005. Magma-assisted rifting in Ethiopia. Nature 433, 146-148.

Kohlstedt, D.L., Zimmerman, M.E., 1996. Rheology of partially molten mantle rocks. Annu. Rev. Earth Planet. Sci. 24 (1), 41-62.

Kohlstedt, D.L., Keppler, H., Rubie, D.C., 1996. Solubility of water in the alpha, beta, and Y phases of (Mg, Fe)2SiO4. Reviews in Mineralogy \& Geochemistry 123, 345-357.

Kovacs, I., O'Neill, H.C.J., Hermann, J., Hauri, E.H., 2010. Site-specific infrared O-H absorption coefficients for water substitution into olivine. Am. Mineral. 95, 292-299.

Kourim, F., Vauchez, A., Bodinier, J.-L., Alard, O., Bendaoud, A., 2014. Subcontinental lithosphere reactivation beneath the Hoggar swell (Algeria): localized deformation, melt channeling and heat advection. Tectonophysics http://dx.doi.org/10.1016/j.tecto. 2014.11.012 (in press).

Kruckenberg, S.C., Tikoff, B., Toy, V.G., Newman, J., Young, L.I., 2013. Strain localization associated with channelized melt migration in upper mantle lithosphere: Insights from the Twin Sisters ultramafic complex, Washington, USA. Journal of Structural Geology 50, 133-147.

Kruckenberg, S.C., Chatzaras, V., Gordon Medaris Jr., L., 2014. Correlations between strain geometry, shape fabric, and crystallographic preferred orientation revealed by microtomography and textural analyses: heterogeneous deformation of mantle xenoliths from Marie Byrd Land, Antarctica (abstract). In: 6th Orogenic Lherzolite Conference, Marrakesh, pp. 4-15 (May 2014).

Kubo, K., 2002. Dunite formation processes in highly depleted peridotite: case study of the Iwanaidake peridotite, Hokkaido, Japan. J. Petrol. 43 (3), 423-448.

Kurosawa, M., Yurimoto, H., Sueno, S., 1997. Patterns in the hydrogen and trace element compositions of mantle olivines. Phys. Chem. Miner. 24 (6), 385-395.

Le Gall, B., et al., 2008. Rift propagation at craton margin. Distribution of faulting and volcanism in the North Tanzanian Divergence (East Africa) during Neogene times. Tectonophysics 448, 1-19.
Le Roux, V., Tommasi, A., Vauchez, A., 2008. Feedback between deformation and melt percolation in an exhumed lithosphere-asthenosphere boundary. Earth Planet. Sci. Lett. 274, 401-413. http://dx.doi.org/10.1016/j.epsl.2008.07.053.

Lee, C.-T., 2001. The Origin, Evolution, and Demise of Continental Lithospheric Mantle: Perspectives from Re-Os Isotopes, Geochemistry, Petrology, and Modeling. Harvard University, (PhD Thesis)

Li, J., Kornprobst, J., Vielzeuf, D., Fabriès, J., 1995. An improved experimental calibration of the olivine-spinel geothermometer. Chin. J. Geochem. 14 (1), 68-77.

Li, Z.-X.A., Lee, C.-T.A., Peslier, A.H., Lenardic, A., Mackwell, S.J., 2008. Water contents in mantle xenoliths from the Colorado Plateau and vicinity: implications for the mantle rheology and hydration-induced thinning of continental lithosphere. J. Geophys. Res. 113 (B9), B09210.

MacDonald, R., Rogers, N.W., Fitton, J.G., Black, S., Smith, M., 2001. Plume-lithosphere interactions in the generation of the basalts of the Kenya Rift, East Africa. J. Petrol 42, 877-900.

MacIntyre, R.M., Mitchell, J.G., Dawson, J.B., 1974. Age of the fault movements in the Tanzanian sector of the East African rift system. Nature 247, 354-356.

Mackwell, S.J., Kohlstedt, D.L., 1990. Diffusion of Hydrogen in Olivine: Implications for Water in the Mantle. J. Geophys. Res. 95, 5079-5088.

Mainprice, D., 1990. A FORTRAN program to calculate seismic anisotropy from the lattice preferred orientation of minerals. Comp. Geosci. 16, 385-393.

Mainprice, D., Hielscher, R., Schaeben, H., 2011. Calculating anisotropic physical properties from texture data using the MTEX open source package. In: Prior, D.J., Rutter E.H., Tatham, D.J. (Eds.), Deformation Mechanisms, Rheology and Tectonics: Microstructures, Mechanics and AnisotropyGeol. Soc. Lond., Spec. Publ. 175-192.

Mainprice, D., Bachmann, F., Hielscher, R., Schaeben, H., 2014. Descriptive tools for the analysis of texture projects with large datasets using MTEX - strength, symmetry and components. Geological Society of London Special Publication. Field Experiment and Theory: In Honour of Ernest Rutter.

Mansur, A.T., Shukrani, M., Timpa, S., Rudnick, R.L., 2014. Granulite-facies xenoliths in rift basalts of Northern Tanzania: age, composition and origin of Archean lower crust. J. Petrol. 55, 1243-1286.

Matsyuk, S.S., Langer, K., 2004. Hydroxyl in olivines from mantle xenoliths in kimberlites of the Siberian platform. Contrib. Mineral. Petrol. 147 (4), 413-437.

Matsyuk, S.S., Langer, K., Hösch, A., 1998. Hydroxyl defects in garnets from mantle xenoliths in kimberlites of the Siberian platform. Contrib. Mineral. Petrol. 132 (2), 163-179.

McKenzie, D., 1978. Some remarks on the development of sedimentary basins. Earth Planet. Sci. Lett. 40, 25-32.

Miller, G.H., Rossman, G.R., Harlow, G.E., 1987. The natural occurrence of hydroxide in olivine. Phys. Chem. Miner. 14 (5), 461-472.

Möller, A., Appel, P., Mezger, K., Schenk, V., 1995. Evidence for a 2 Ga subduction zone: eclogites in the Usagaran belt of Tanzania. Geology 23, 1067-1070.

Möller, A., Mezger, K., Schenk, V., 1998. Crustal age domains and the evolution of the continental crust in the Mozambique Belt of Tanzania: combined Sm-Nd, Rb-Sr, and $\mathrm{Pb}-\mathrm{Pb}$ isotopic evidence. J. Petrol. 39, 749-783.

Morgan, Z.T., Liang, Y., 2003. An experimental and numerical study of the kinetics of harzburgite reactive dissolution with applications to dunite dike formation. Earth Planet. Sci. Lett. 214, 59-74.

Morley, C.K., Wescott, W.A., Stone, D.M., Harper, R.M., Wigger, S.T., Karanga, F.M., 1992. Tectonic evolution of the northern Kenya rift. J. Geol. Soc. Lond. 149, 333-348.

Nickel, K.G., Green, D.H., 1985. Empirical geothermobarometry for garnet peridotites and implications for the nature of the lithosphere, kimberlites and diamonds. Earth and Planetary Science Letters 73, 158-170.

Nicolas, A., Bouchez, J.L., Boudier, F., 1972. Interprétation cinématique des déformations plastiques dans le massif de lherzolite de Lanzo (Alpes piémontaises) - comparaison avec d'autres massifs. Tectonophysics 14, 143-171.

Nicolas, A., Achauer, U., Daignieres, M., 1994. Rift initiation by lithospheric rupture. Earth Planet. Sci. Lett. 123, 281-298.

Nyblade, A.A., Brazier, R.A., 2002. Precambrian lithospheric controls on the development of the East African rift system. Geology 30 (8), 755-758.

Nyblade, A., Birt, C., Langston, C.A., Owens, T.J., Last, R.J., 1996. Seismic experiment reveals rifting of craton in Tanzania. Eos Trans. Am. Geophys. Union 77 (51), 517-521.

Padrón-Navarta, J.A., Tommasi, A., Garrido, C.J., López Sánchez-Vizcaíno, V., GómezPugnaire, M.T., Jabaloy, A., Vauchez, A., 2010. Fluid transfer into the wedge controlled by high-pressure hydrofracturing in the cold top-slab mantle. Earth Planet. Sci. Lett. 297 (1-2), 271-286.

Padrón-Navarta, J.A., Hermann, J., O'Neill, H., 2014. Site-specific hydrogen diffusion rates in Forsterite. Earth Planet. Sci. Lett. 392, 100-112.

Paterson, M.S., 1982. The determination of hydroxyl by infrared absorption in quartz, silicate glasses and similar materials. Bull. Mineral. 105 (1), 20-29.

Peslier, A.H., 2010. A review of water contents of nominally anhydrous natural minerals in the mantles of Earth, Mars and the Moon. J. Volcanol. Geotherm. Res. 197 (1-4), 239-258.

Peslier, A.H., Luhr, J.F., 2006. Hydrogen loss from olivines in mantle xenoliths from Simcoe (USA) and Mexico: mafic alkalic magma ascent rates and water budget of the subcontinental lithosphere. Earth Planet. Sci. Lett. 242 (3-4), 302-319.

Peslier, A.H., Luhr, J.F., Post, J., 2002. Low water contents in pyroxenes from spinel-peridotites of the oxidized, sub-arc mantle wedge. Earth Planet. Sci. Lett. 201 (1), 69-86.

Peslier, A.H., Woodland, A.B., Wolff, J.A., 2008. Fast kimberlite ascent rates estimated from hydrogen diffusion profiles in xenolithic mantle olivines from southern Africa. Geochim. Cosmochim. Acta 72 (11), 2711-2722.

Peslier, A.H., Woodland, A.B., Bell, D.R., Lazarov, M., 2010. Olivine water contents in the continental lithosphere and the longevity of cratons. Nature 467, 78-81.

Phakey, P., Dollinger, G., Christie, J.M., 1972. Transmission electron microscopy of experimentally deformed olivine. Flow and fracture of rocks. Geophys. Monogr. 16, 117-138. 
Pinna, P., Jourde, G., Calvez, J.Y., Mroz, J.P., Marques, J.M., 1993. The Mozambique Belt in northern Mozambique: Neoproterozoic (1100-850 Ma) crustal growth and tectogenesis, and superimposed Pan-African (800-550 Ma) tectonism. Precambrian Res. 62, 1-59.

Raleigh, C.B., 1968. Mechanisms of plastic deformation of olivine. J. Geophys. Res. 73 (16) 5391-5406.

Raterron, P., Amiguet, E., Chen, J.H., Li, L., Cordier, P., 2009. Experimental deformation of olivine single crystals at mantle pressures and temperatures. Phys. Earth Planet. Inter. 172 (1-2), 74-83.

Rudnick, R.L., McDonough, W.F., Chappell, B.W., 1993. Carbonite metasomatism in the northern Tanzanian mantle: petrographic and geochemical characteristics. Earth Planet. Sci. Lett. 114, 463-475.

Rudnick, R.L., McDonough, W.F., Orpin, A., 1994. Northern Tanzanian peridotite xenoliths: a comparison with Kaapvaal peridotites and inferences of metasomatic interactions. In: Meyer, H.O.A., Leonardos, O.H. (Eds.), Kimberlites, Related Rocks and Mantle Xenoliths. Proceedings of the 5th International Kimberlite Conference, pp. 336-353.

Ruotoistenmäki, T., 2014. Geophysical characteristics of Aswa shear, Nagasongola discontinuity and ring dyke complex in Uganda. J. Afr. Earth Sci. 93, 23-41.

Ryan, W.B.F., Carbotte, S.M., Coplan, J.O., O'Hara, S., Melkonian, A., Arko, R., Weissel, R.A. Ferrini, V., Goodwillie, A., Nitsche, F., Bonczkowski, J., Zemsky, R., 2009. Global multi-resolution topography synthesis. Geochem. Geophys. Geosyst. 10, Q03014. http://dx.doi.org/10.1029/2008GC002332.

Sachtleben, T., Seck, H.A., 1981. Chemical control of Al-solubility in orthopyroxene and its implications on pyroxene geothermometry. Contrib. Mineral. Petrol. 78, 157-165.

Sicilia, D., Montagner, J.-P., Cara, M., Stutzmann, E., Debayle, E., Lépine, J.-C., Lévêque, J.Beucler, E., Sebai, A., Roult, G., Ayele, A., Sholan, J.M., 2008. Upper mantle structure of shear-waves velocities and stratification of anisotropy in the Afar Hotspot region. Tectonophysics 462, 164-177.

Sokol, A.G., Palyanov, Y.N., Kupriyanov, IN , Litasov, K.D., Polovinka, M.P., 2010. Effect of oxygen fugacity on the $\mathrm{H}_{2} \mathrm{O}$ storage capacity of forsterite in the carbon-saturated systems. Geochim. Cosmochim. Acta 74, 4793-4806.

Soustelle, V., Tommasi, A., Bodinier, J.-L., Garrido, C.J., Vauchez, A., 2009. Deformation an reactive melt transport in the mantle lithosphere above a large-scale partial melting domain: the Ronda peridotite massif, southern Spain. J. Petrol. 50 (7), 1235-1266.

Soustelle, V., Tommasi, A., Demouchy, S., Ionov, D.A., 2010. Deformation and fluid, a rock interaction in the supra-subduction mantle: microstructures and water contents in peridotite xenoliths from the Avacha Volcano, Kamchatka. J. Petrol. 51 (1-2) 363-394.

Soustelle, V., Tommasi, A., Demouchy, S., Franz, L., 2013. Melt-rock interactions, deformation, hydration and seismic properties in the sub-arc lithospheric mantle inferre from xenoliths from seamounts near Lihir, Papua New Guinea. Tectonophysics 608 , 330-345.

Thoraval, C. Demouchy, S., 2014. Numerical models of ionic diffusion in one and three dimensions: application to dehydration of mantle olivine. Phys. Chem. Miner. 41, 709-723.

Tommasi, A., Vauchez, A., 2001. Continental rifting parallel to ancient collisional belts: an effect of the mechanical anisotropy of the lithospheric mantle. Earth Planet. Sci. Lett. $185,199-210$

Tommasi, A., Tikoff, B., Vauchez, A., 1999. Upper mantle tectonics: three-dimensiona deformation, olivine crystallographic fabrics and seismic properties. Earth Planet. Sci. Lett. 168 (1-2), 173-186.

Tommasi, A., Mainprice, D., Canova, G., Chastel, Y., 2000. Viscoplastic self-consistent and equilibrium-based modeling of olivine lattice preferred orientations: implication for the upper mantle seismic anisotropy. J. Geophys. Res. 105 (B4), 7893-7908.
Tommasi, A Godard, M., Coromina, G., Dautria, J-M., Barsczus, H., 2004. Seismic anisotropy and compositionally induced velocity anomalies in the lithosphere above mantle plumes: a petrological and microstructural study of mantle xenoliths from French Polynesia. Earth Planet. Sci. Lett. 227 (3-4), 539-556.

Tommasi, A., Vauchez, A., Ionov, D.A., 2008. Deformation, static recrystallisation, and reactive melt transport in shallow subcontinental mantle xenoliths (Tol Cenozoic volcanic field, SE Siberia). Earth Planet. Sci. Lett. 272 (1-2), 65-77.

Tommasi, A., Knoll, M., Vauchez, A., Signorelli, J., Thoraval, C., Loge, R., 2009. Structural reactivation in plate tectonics controlled by olivine crystals anisotropy. Nat. Geosci. 2, 423-427.

Tubìa, J.M., Cuevas, J., Esteban, J.J., 2004. Tectonic evidence in the Ronda peridotites, Spain, for mantle diapirism related to delamination. Geology 32 (11), 941-944.

Vauchez, A., Barruol, G., Tommasi, A., 1997. Why do continents break-up parallel to ancient orogenic belts? Terra Nova 9, 62-66.

Vauchez, A., Tommasi, A., Barruol, G., Maumus, J., 2000. Upper mantle deformation and seismic anisotropy in continental rifts. Phys. Chem. Earth 25 (2), 111-117.

Vauchez, A., Dineur, F., Rudnick, R.L., 2005. Microstructure, texture and seismic anisotropy of the lithospheric mantle above a mantle plume: insights from the Labait volcano xenoliths. Earth Planet. Sci. Lett. 232 (3-4), 295-314.

Vauchez, A., Tommasi, A., Mainprice, D., 2012. Faults (shear zones) in the Earth's mantle. Tectonophysics 558-559, 1-27.

Vollmer, F.W., 1990. An application of eigenvalue methods to structural domain analysis. Geol. Soc. Am. Bull. 102, 786-791.

Walker, K.T., Nyblade, A.A., Klemperer, S.L., Bokelmann, G.H.R., Owens, T.J., 2004. On the relationship between extension and anisotropy: constraints from shear wave splitting across the East African Plateau. J. Geophys. Res. 109 (B08302), 1-21.

Wells, P.R.A., 1977. Pyroxene thermometry in simple and complex systems. Contrib. Mineral. Petrol. 62, 129-139.

Wernicke, B., 1981. Low angle normal faults in Bassin and Range province. Nappe tectonics in an extending orogen. Nature 291, 645-648.

Wernicke, B., 1985. Uniform-sense normal simple shear of the continental lithosphere. Can. J. Earth Sci. 22, 108-125.

Wilkinson, P., Mitchell, J.G., Cattermole, P.J., Downie, C., 1986. Volcanic chronology of the Meru-Kilimanjaro region, Northern Tanzania. J. Geol. Soc. Lond. 143, 601-605.

Withers, A.C., Bureau, H., Raepsaet, C., Hirschmann, M.M., 2012. Calibration of infrared spectroscopy by elastic recoil detection analysis of $\mathrm{H}$ in synthetic olivine. Chem. Geol. 334, 92-98.

Witt-Eickschen, G., Seck, H.A., 1991. Solubility of Ca and Al in orthopyroxene from spinel peridotite: an improved version of an empirical geothermometer. Contrib. Mineral. Petrol. 106 (4), 431-439.

Yang, X.-Z., Xia, Q.-K., Deloule, E., Dallai, L., Fan, Q.-C., Feng, M., 2008. Water in minerals of the continental lithospheric mantle and overlying lower crust: a comparative study of peridotite and granulite xenoliths from the North China Craton. Chem. Geol. 256 (1-2), 33-45.

Zaffarana, C., Tommasi, A., Vauchez, A., Grégoire, M., 2014. Microstructures and seismic properties of south Patagonian mantle xenoliths (Gobernador Gregores and Pali Aike). Tectonophysics 621, 175-197. http://dx.doi.org/10.1016/j.tecto.2014.02.017.

Zimmerman, M.E., Kohlstedt, D.L., 2004. Rheological properties of partially molten lherzolite. J. Petrol. 45 (2), 275-298. 